\title{
REFLECTIONS ON TIME AND PLACE: THE NOVA SCOTIAN INSTITUTE OF SCIENCE IN ITS FIRST 150 YEARS
}

\author{
SUZANNE ZELLER \\ Department of History, Wilfrid Laurier University \\ Waterloo, Ontario N2L 3 C5
}

"The universal flux and flow of the world is seen also in our little college."

(Dalhousie Gazette 1913:2)

The Nova Scotian Institute of Science's [hereafter NSIS] sesquicentenary in 2012 offers an opportune moment in the Institute's lengthy history to celebrate an impressive cumulative record of achievement over time. In so doing, we can assess the NSIS's place in the same "universal flux and flow of the world" that buffeted its partner institution, Dalhousie University, in a rapidly changing historical context. From its inception, the NSIS mandated annual assessments by its presidents, who have traditionally taken more detailed stock of its state of affairs at 25-year intervals (Piers 1915; Piers 1936; Fergusson 1964). To mark its $75^{\text {th }}$ anniversary in 1937, NSIS members even contemplated commissioning a history for publication in a scholarly journal; the Council, however, tabled the suggestion in favour of a public event that would make a bigger splash (NSIS Council Minutes 1936: 26 October; NSIS 1936a).

In addition to the manuscript Minutes of NSIS meetings housed in the Nova Scotia Archives, the Institute's remarkable unbroken series of published Proceedings and Transactions ${ }^{1}$ sheds valuable light on the ways in which discussion translated into action. This substantial cumulative historical record also reveals longterm challenges faced by an ambitious institution dedicated to "the promotion of science" - a mission that began as a measure of Nova Scotia's material and cultural progress in the modern world, changing its meaning over time in ways that repeatedly challenged the Institute's understanding of its place in that world.

1 Less unbroken, however, are the NSIS membership records, reported only sporadically at best and often including names with unpaid dues. Membership numbers have, thankfully, been included once again, this time in NSIS Treasurers' annual reports, since 2004. 
Recent scholarship has, in addition, deepened our understanding of time and place in the history of science and its institutions. On the temporal front, the historian John V. Pickstone identifies three predominant Ways of Knowing (2001) that have characterized the practices of science, technology, and medicine as they too changed over time. What Pickstone calls Natural Historical, Analytical, and Experimentalist Ways of Knowing each displaced - but emphatically did not replace - the others in a particular historical sequence. Before Pickstone, the early NSIS seemed to exemplify a natural history society; after Pickstone, we understand it more clearly as a creature of the 19th-century Age of Analysis, intended to promote the production of a specific range of scientific knowledge by analytical means, and to communicate the results in analytical forms. In a telling signal on this point, repeated NSIS efforts to organize the four annual field excursions required in its by-laws never attracted the following that natural history societies elsewhere were able to rally, and were soon discontinued (Gossip 1878:229; Ritchie 1926a:xxix; Fergusson 1962:233).

On the spatial front, the historical geographer David N. Livingstone's Putting Science in Its Place (2003) distinguishes three geographical dimensions in the production of scientific knowledge:the Sites (including field, museum, and laboratory) and Regions from which such knowledge emerges; and the patterns of Circulation that explain how (and in what forms) such knowledge travels from one place (and context) to another. Livingstone's spatial approach encourages historians of the NSIS to move beyond classic assumptions of a one-way diffusion of scientific knowledge and practice from imperial centres to colonial peripheries - or, for that matter, from Halifax to its provincial hinterland (Basalla 1963; Corfield 2003:90-92). Metropolitan approaches overlook Halifax's role as more complex than a mere harbour for British exploratory expeditions to replenish their supplies en route to somewhere else, on the one hand; they also overemphasize its role as the urban arbiter of Nova Scotian science, on the other hand.

When Britain's HMS Challenger docked at Halifax ${ }^{2}$ in May 1873 during its pioneering scientific investigation of the oceans in various latitudes (Mills 1975; Mills 1989), one of its leading scientists, the Scottish marine zoologist Sir Charles Wyville Thomson (1830-82)

\footnotetext{
2 So did its scientific predecessors HMSS Porcupine and Lightning (Honeyman 1874;
} Bailey 1972). 
disembarked to visit with two Scottish colleagues, the botanist George Lawson (1827-95), who happened to be away, and the geologist David Honeyman (1817-89). Both were senior NSIS members, with Honeyman also founding curator of the NSIS's institutional offspring, the Nova Scotia Provincial Museum [now the Nova Scotia Museum of Natural History], established in 1868. These professional connections opened the Challenger to hundreds of interested Haligonians for an unforgettable guided tour - not only of the state-of-the-art "apparata" used to dredge new natural wonders from the ocean floor, but also of the scientists' ship-board working quarters. Before departing, the Challenger scientists enjoyed a field excursion with Honeyman guiding them to photograph local glacial striations at Point Pleasant (Fig 1), and accepting in return some coveted specimens recently raised from their deep-sea habitats (Honeyman 1873).

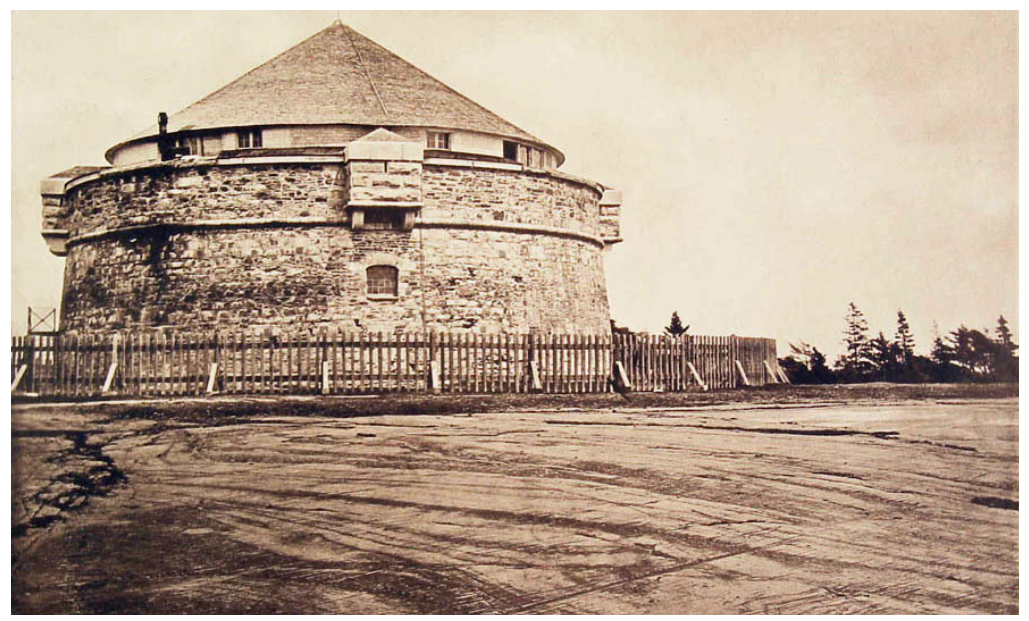

Fig 1 "Rock with Glacial Markings, Halifax, Nova Scotia" (Source: C. Wyville Thomson and John Murray, Report of the Scientific Results of the Voyage of H.M.S. Challenger During the Years 1873-76, Vol. 1, Photographic Plate I (London: Eyre and Spottiswoode, 1885) 158, accessed 14 January 2014 http://www.19thcenturyscience.org/HMSC/HMSC-Reports/1885-Narrative/ Plates.html).

Pickstone's and Livingstone's insights alert historians to the significance of such transfers of knowledge between the NSIS, its wider Atlantic world, and indigenous and local informants (Jones 1867; Ambrose 1867); of the NSIS's purposeful inclusion of Prince Edward Island, Newfoundland, Labrador, and Bermuda in its purview (Hill 1867:4); and of the historical experiences - including a shift in 
emphasis from the field to the laboratory - that compelled the NSIS time and again to reconsider its relationship to the place from which it took its name. Indeed, the history of its first fifty years reveals themes that would exalt - and challenges that would haunt - the NSIS for the fifty years that followed, with a return to more familiar ground thereafter.

\section{SETTING SAIL}

Established in 1749 as a crucial node of in an expanding British Empire, Halifax grew into a busy crossroads where an amalgam of cultures, among them strong Scottish influences, embraced science increasingly as indispensable to modern life. Yet early attempts, in the mode of the British amateur naturalist tradition, to organize formally those who shared a passion to observe, collect, describe, and classify the floral, faunal, and mineral denizens of Nova Scotia's remarkable landscape enjoyed little success before other important developments came into play. The 1860s were not an age for founding natural history societies, but rather for what Pickstone differentiates as Analytical work that built on, rationalized, and extended natural history's descriptive inquiries to support industrial development's voracious appetite for natural resources in a rapidly changing world.

During the uncertain decades after the end of the Napoleonic Wars in 1815, frustrations over Nova Scotia's economic future only intensified when the colony's most prominent scientist, (Sir) JW Dawson (1820-99), whose classic study of Acadian Geology made his name internationally in 1855 , left that same year to become principal of McGill College, Montreal. While the end of the (British) General Mining Association's thirty-year monopoly over mineral rights in Nova Scotia in 1857 at last opened the colony's wealth of mineral resources to the possibility of a thorough scientific appraisal, American mining companies were eager to move in before that goal could be accomplished. Even when "gold fever" (Poole 1906:xx) gripped the colony during the 1860 s, the Nova Scotia government resisted calls to appoint a geological survey on the model of Sir William Logan's Geological Survey of Canada, established twenty years earlier to locate, assess, and map whatever mineral deposits promised the United Province of Canada (now Ontario and Quebec) industrial wealth on the scale enjoyed by Great Britain and the United States (Nuftel 2003; Zeller 2009). 


\section{A. Foundations}

The success of Nova Scotia's prize-winning mineralogical display at the Great London Exhibition in 1862 galvanized David Honeyman and a handful of fellow exhibition organizers later that year to convene the Nova Scotian Institute of Natural Science, a successor to the Halifax Mechanics' Institute (1831-62), the Halifax Literary and Scientific Society (1839-46) and the Nova Scotia Literary and Scientific Society (1859-62) (Piers 1915; Fergusson 1962). The reorganization of Dalhousie College in 1863 offered no hope of immediate reinforcement for the fledgling society, as dire financial difficulties precluded all scientific possibilities at the college for the time being - except for a much-needed NSIS meeting room and the arrival (as Professor of Chemistry and Mineralogy) of the botanist George Lawson, a refugee from an even more deeply troubled Queen's College, Kingston (Waite 1994, Chapter 5; Zeller 2003).

In favouring Ways of Knowing well beyond those practised in natural history, the NSIS saw continuing interest in observing, describing, and classifying nature open out to Analytical searches for units in nature as components of larger systems. While Natural Historical Ways of Knowing had recorded the process of encountering nature until about 1815, Analytical Ways of Knowing thereafter sought to impose order, to subdue nature (Wynn 2007), dissecting it to reveal its parts. The aim, in Pickstone's terms, was to "rationalize production," not only through mechanization but also by reconceptualizing even living organisms as components of processes that could be broken down, standardized, and, ultimately, commodified (Pickstone 2001: Chapters 2-3). For the fledgling NSIS, it was not simply a matter of engaging geology, mineralogy, and chemistry to harvest the colony's known mineral wealth more efficiently, but of promoting all branches of science that could help to rationalize fishing, farming, hunting, manufacturing, and other professional and commercial pursuits, with an eye to rendering every livelihood - and every worker - more productive (Dewar 1865; Reid 1876).

The early life of the NSIS drew Analytical inspiration from the "Prince of Modern Science," the recently "lamented" Prussian scientific traveller Alexander von Humboldt (1769-1859) whose widely admired works culminated in his multi-volume Cosmos (1845-62), an attempt at nothing less than a Physical Description of the Universe by investigating nature's underlying interconnectedness. The "distinguished modern," as Thomas Knight reminded the Institute in 1869, "was 
the first who employed such wonderful powers of generalization in comprehending the vastness and oneness of nature" (Knight 1870:98). Humboldt lent these interconnections effective visual expression in the Analytical maps, isolines, tables, graphs, and charts that populated not only the Atlas that accompanied Cosmos, but also the pages of the NSIS Proceedings and Transactions with increasing sophistication over the years. Scientific knowledge accrued, in the Humboldtian view, through the cooperation of widely dispersed participants using standardized instruments in synchronized observations. In return, it promised the greatest possible accuracy in the search for patterns in nature that would ultimately reveal natural laws. Humboldt's worldwide networks of scientific communication and exchange constituted a feat of incredible proportions long before the internet enabled later generations to take WorldWide Webs of knowledge for granted. His Analytical leadership inspired British military officers and even fur traders to contribute to the growth of scientific knowledge from the far corners of the natural and physical world to which they travelled (Zeller 2012). In his inaugural presidential address, Nova Scotia's Provincial Secretary, PC Hill, reminded the NSIS of its important vantage point in this regard: "Nothing is more characteristic of the science of the present day," he pointed out, "than the value attached to facts verified and ascertained in situ" (Hill 1867:2).

From the outset, as a result, the NSIS determined to publish regular transactions not only for the regional value of its findings, which won government funding amid perennial hopes of undiscovered gold deposits - fortified by new geological theories for locating them (Gilpin 1878:387; Stafford 1989:19). The Proceedings and Transactions were, furthermore, intended to produce scientific knowledge that thus became "the property of the whole world" (Hill 1867:2), where the relevance of revolutionary new theories regarding the origin and distribution of species and the wonderfully transformative powers of energy science engaged early NSIS members in regular discussions (NSIS Council Minutes 1864: 7 November and 5 December; Belt 1867; Fraser 1868; Ross, 1874; Dewar 1879). Soon NSIS officers were proudly reporting its Proceedings and Transactions "in great demand" as far as Europe and even Australia (Mellish 1878:105; Gossip 1878:227).

The sweet smell of success in attracting public support inflated NSIS members' dreams: of an Academy or Hall of Science with the means to encourage further scientific investigation (Reid 1872a; Gossip 1884); of a provincial aquarium for the study of marine zoology 
(Reid 1872a; Reid 1876:132-33, 135); of a provincial science library (Gossip 1878:228); of microscopes and other scientific instruments that could be lent out to NSIS members (Gossip 1879:105); and of a school of practical science to match recent achievements on this front in Toronto and Montreal (Zeller 2000). While announcements of a new Halifax Technological Institute, presided over by George Lawson and staffed by NSIS and Dalhousie College colleagues on a voluntary basis, attracted students eager for vocational training during the academic years 1878-80, high hopes for the necessary public funding - and even for a building - to keep it going were just as quickly dashed at every government level (Gilpin 1878:379; NSIS 1879).

The still-born Halifax Technological Institute exposed structural fault-lines that challenged the NSIS more generally throughout its history. First and foremost, geography conspired with $19^{\text {th }}$-century modes of travel to make it impossible (and later impractical) for even the most ardent supporters in the Nova Scotian countryside to attend meetings in Halifax on a regular basis (NSIS 1879). Some members also felt constrained by the NSIS's original vision: the Edinburghtrained physician Dr. AP Reid (1836-1919) had urged the Nova Scotian Institute of Natural Science as early as 1872 to embrace the interest in modern physical science and technology already reflected throughout its Proceedings and Transactions (Reid 1872b). Despite resistance from George Lawson and others, Reid successfully moved a resolution in 1874 to divide the NSIS into three sections (Natural History, Ethnology, and Technology), a decision that altered little in the Institute's unified operations ${ }^{3}$ (Reid 1874). A changing context, however, soon recast these discussions of the NSIS's structure, aim, and purpose.

\section{B. Research Ideal}

In 1882 the newly established Royal Society of Canada [hereafter $\mathrm{RSC}$ ] introduced a powerful external force field that polarized the Institute. With an exclusive membership in two elite scientific (and two literary) academies (Levere 1998; Berger 1996), the RSC threatened to fracture the scholarly energies - if not the scholarly loyalties - of NSIS members who found themselves so anointed. Moreover, an RSC invitation to institutional membership, with expectations of

These groups met occasionally outside of the formal framework of regular NSIS meetings; the index to the subsequent volume of the Proceedings and Transactions (Volume 3 ) - and only that one - was subdivided in a similar (but not identical) way. 
a commitment to elect representatives and send reports to its annual meetings, sparked concerns for the NSIS's future independence. ${ }^{4}$

Of the six NSIS members who were named RSC charter fellows, five had longstanding NSIS ties. ${ }^{5}$ The sixth, the dynamic James Gordon MacGregor (1852-1913), had joined in 1877. A prize-winning Dalhousie graduate (BA 1871; MA 1874), MacGregor had proceeded overseas on a Gilchrist Scholarship, first to the University of Edinburgh, where he spent invaluable time in the laboratory of the renowned physicist Peter Guthrie Tait ${ }^{6}$ (1831-1901); and then to the University of Leipzig, where he cemented a lifelong research interest in thermal and electrical chemistry in the laboratory of the physical chemist Gustav Wiedemann (1826-99). MacGregor then completed a DSc at the University of London in 1876. Stints as a sessional lecturer in physics at Dalhousie (1876-77) - strongly supported by the NSIS (Gossip 1876) - and then as physical science master at Clifton College, Bristol (1877-79) came to a merciful end when the unprecedented endowment that saved Dalhousie from financial collapse (and the death of its physics professor, JJ MacKenzie) in 1879 afforded MacGregor's appointment to the inaugural George Munro Chair of Physics (Waite 2003; NSIS 1919b:lxxxvi; Knott 1913:323).

In keeping with his specialization in the cutting-edge field of thermodynamics, MacGregor showed himself a force of nature who reconfigured the NSIS in his own image of Analytical science as the path to progress in the modern world. In so doing, he exposed the RSC's divisive impact through an open challenge to Dr. John Somers (?-1898), the NSIS president, whose (unpublished) annual address in 1882 criticized the RSC's letter of invitation for unduly patronizing the NSIS. In a blatant rebuke of Somers, MacGregor, seconded by George Lawson, steered a discussion to welcome the RSC's invitation and to elect a delegate to its inaugural meeting in Ottawa (NSIS Council Minutes 1883:2, 8, and 31 January). ${ }^{7}$

\footnotetext{
4 The NSIS was not alone in these concerns (Lawson 1889: 1-3; Grant 1892:xxxi).

5 They were Edwin Gilpin (1850-1907), JB Gilpin (1810-92), David Honeyman, JM Jones (1822-88), and George Lawson.

6 Tait was one of the North British researchers who, led by William Thomson (later Lord Kelvin) (1824-1907) was revolutionizing classical physics through the powerful new science of heat as a form of energy, thermodynamics, with brilliant applications of mathematical analysis to improve the efficiency of steam-based machinery (Smith 1999).

7 MacGregor then turned his critical eye toward RSC procedures at its Halifax meeting in 1897 (MacGregor: personalia (1913):28).
} 
Nor did the election of William Gossip (1809-89), a Halifax publisher, NSIS Council member, and founding editor of its Proceedings and Transactions, bridge the fundamental gap between NSIS specialists and generalists. Gossip arrived at the RSC meeting to confess that he had prepared no report on NSIS activities, submitting instead a personal commentary on the RSC's responsibilities towards its affiliated societies; it was all MacGregor could do to dissuade him from reading the statement into the RSC Minutes. ${ }^{8}$ Gossip reported back to the NSIS in descriptive detail the impressions of a neophyte railway traveller, Ottawa tourist, and conference participant who harboured serious misgivings about the RSC's organizational structure, especially with its membership "numbers so unwisely limited" (Gossip 1884; Gossip 1885). While MacGregor conceded that the RSC was indeed siphoning off the NSIS Proceedings and Transactions' best papers, he held out hope that "before very long, the establishment of the Royal Society may result in a stimulus which will produce so much energetic work, that the Transactions of both the central and the local Societies may be large as to number and valuable as to contents" (MacGregor 1886b:x). Before very long, however, the NSIS found itself permitting papers presented at its meetings to be published in its Proceedings and Transactions even when they were also committed elsewhere (NSIS Council Minutes 1895:31 December; MacGregor 1898:xxvi).

MacGregor described this change in NSIS policy as "a great relief" (MacGregor 1898:xxvi), since both he and Lawson thrived in their more expansive scholarly environment. Lawson, in particular, had made clear that he had hesitated to publish in the Proceedings and Transactions while the NSIS "made little effort to distribute its publications among scientific societies" (Hall 1896). Having imbibed the German research ideal, which advocated scientific research "for its own sake," independent of metaphysical or religious concerns ${ }^{9}$ (McKillop 1982:79-80; McKillop 1994:Chapter 7), MacGregor set about modernizing the NSIS - and with it Nova Scotian science

8 The RSC Proceedings listed Gossip's submission among those that "gave to the meeting encouraging oral statements of the work that was being done" (RSC 1883:xlv).

9 As one memorialist later explained, MacGregor's "personal philosophy took shape in the time of the great [John] Tyndall [materialist] and [Thomas] Huxley [agnostic] wars with accepted beliefs" (MacGregor: personalia 1913:28). George Lawson, with a DPhil and laboratory experience from the University of Giessen, shared the German research ideal; as RSC vice president in 1887, he repeated the mantra that "Science is best pursued for its own sake" (Lawson 1888:xxiv). 
education - to promote "knowledge-making" accordingly (MacGregor 1899). In 1884, after initiating a worldwide RSC survey of scientific institutions' means of funding research, he revised the NSIS by-laws to specify as the Institute's single object "the promotion of scientific research," which he deemed, in characteristic Analytical style, "essential to the promotion of our industrial development" (RSC 1883:xv; MacGregor 1886a; NSIS Minutes 1884:24 October; NSIS 1885:1; cf. NSIS 1863:1; MacGregor 1890b:328).

MacGregor's election to the NSIS presidency in 1888 followed the Institute's first 25-year mark with still more far-reaching changes. In an unprecedented flurry of NSIS activity, he introduced an integrated plan to strengthen the Institute and, along with it, science education across the province (MacGregor 1899). The linchpin was to be the Provincial Museum, with the NSIS driving the Museum's development as the repository for a new provincial science library, a showcase for the province's natural resources, and the locus for a range of new science educational opportunities, both specialized and popular. Recalling the trials of the nascent Halifax Technical Institute - to which he had been deeply committed as a leading protagonist MacGregor revived his mission to interest Nova Scotians in science, both "pure and applied" (MacGregor 1890b; NSIS 1919b:lxxxviii).

In 1890 MacGregor accordingly rebranded the NSIS to acknowledge certain realities. "The scope of [its] exertions," he explained, had "got beyond the range of the departments of science indicated by its name." More pointedly, "the old name" created impressions of "a society of naturalists," thereby "repress[ing] the interest which [those] engaged in other departments of work might have taken in it." As such, it "hamper[ed] ... our endeavour to secure by exchange the publications of other societies ... devoted to departments not usually included under the term Natural Sciences." MacGregor accordingly urged the NSIS formally "to extend its field to all departments of science, pure and applied, encourage research in all such departments and build up, by exchange, a library for the use of those engaged in them." A special meeting in March marked the end of an era in NSIS history by amending its name (choosing "Nova Scotian Institute of Science" over "Nova Scotian Scientific Institute") and securing the organization's incorporation later that same year. Eyewitness recollections long afterwards denied the unanimity so starkly recorded 
in the NSIS Minutes,${ }^{10}$ instead citing "considerable opposition" that persisted for decades and included "one of the most learned biologists of the United States"11 (NSIS Minutes 24 March 1890; Fergusson 1962:236; Piers 1915:lxxi-lxxiii; Ritchie 1926:xxxi).

MacGregor hoped, above all, to breathe new life into the Institute's memberships and exchanges. In charts and graphs ${ }^{12}$ that again reflected his Analytical approach, he assessed the NSIS's historical record of achievement (MacGregor 1890a:185-186) along three axes that comprised its mandate: not just "investigating" and "providing the means of investigating," but also, he explained, "stimulating the love of investigation" - the last having grown more difficult as even the comprehension, let alone the practice, of science required increasingly specialized training (MacGregor 1890a:189).Embarking on a tireless science awareness campaign throughout the province, MacGregor targetted school teachers and their students as potential NSIS members, urging NSIS colleagues similarly to extend invitations to friends and acquaintances. In a related move, as editor of the Proceedings and Transactions (1890-1901), he raised the journal's print run to an unprecedented 1000 copies, adding 300 international exchanges during the first year alone, with a "phenomenal" upward trajectory that garnered government funds to ease the burden of mailing, binding, cataloguing, storing, and insuring the rapidly growing core of what became the new Provincial Science Library in 1890 (Fig 2) (NSIS Council Minutes 1890s, passim; MacGregor 1892ab; Ritchie 1926a:xxix). A concomitant rise in NSIS memberships (Fig 3 ) reflected growth especially in the Associate and Corresponding member categories (figs. 4 and 5).

In 1891 the indefatiguable MacGregor completed three eventful years as NSIS president, regretting his failure to secure a building for the Provincial Museum, a goal that would have to wait another ten years before it saw the light of day (MacGregor 1892b:xxxiv).

${ }^{10}$ Harry Piers's later claim that John Somers led a group of older opponents to the name change fits with Somers's refusal as a physician, even during the mid-1890s, to accept scientific research that supported the germ theory of disease. The literature also hints at another longterm rivalry, between Edinburgh- and Aberdeen-based traditions in scientific training (Lawson 1896:vi-vii; Howell 2003).

11 This was likely the New Brunswick-born W.F. Ganong (1864-1941), Professor of Botany at Smith College, who joined the NSIS as a Corresponding Member in 1890 (Bean 1942:289-90); that same year, Ganong co-authored a paper with Harry Piers, whose recollection is cited above on this point.

12 The NSIS archives have, unfortunately, no copies. 


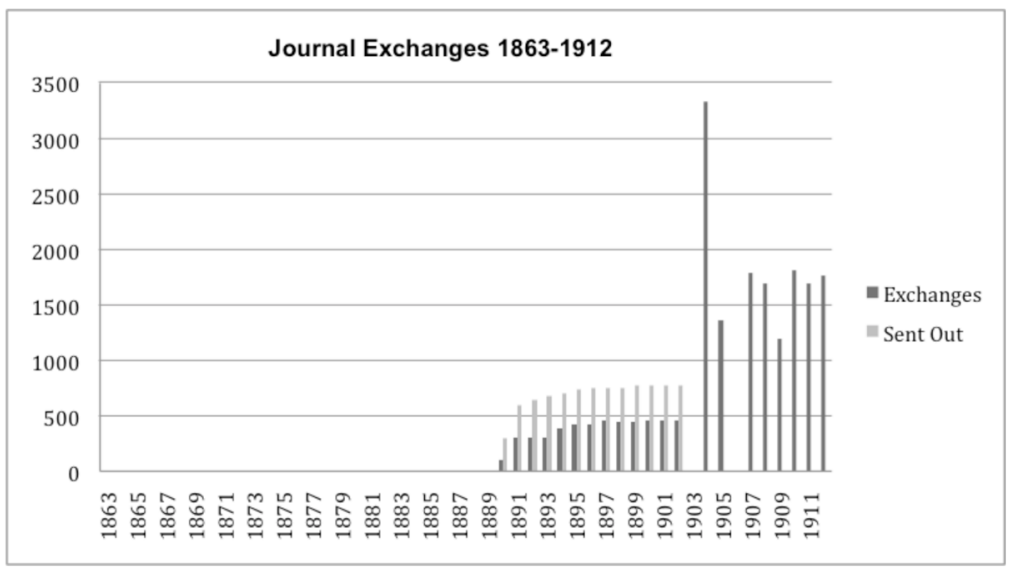

Fig 2 NSIS Journal Exchanges, 1863-1912.

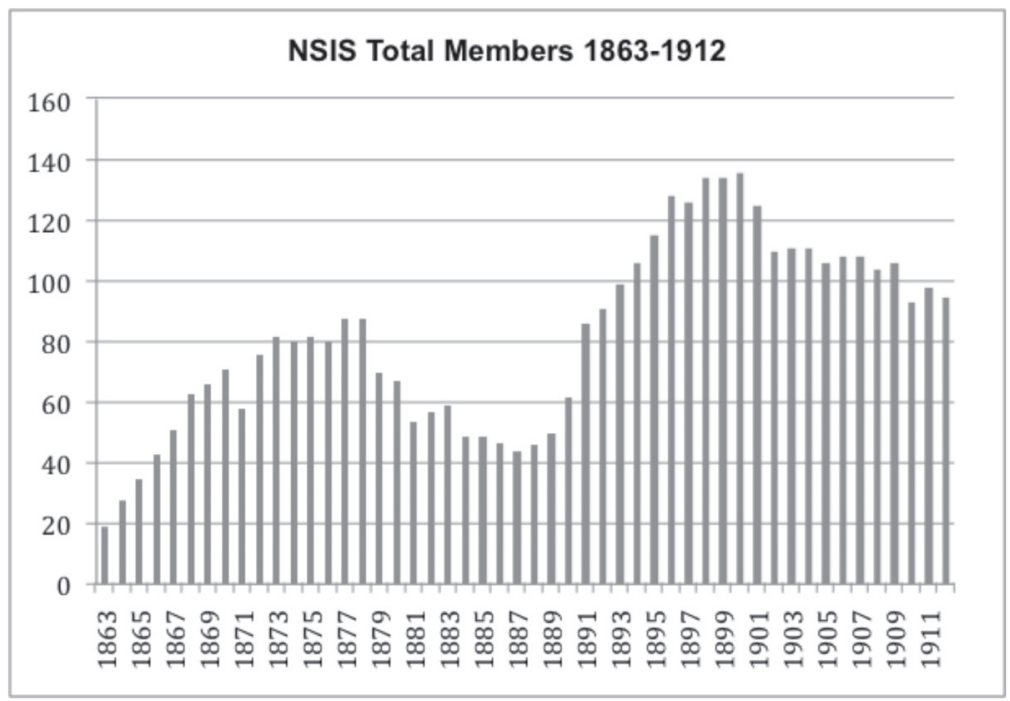

Fig 3 NSIS Total Members, 1863-1912.

Soon thereafter, however (and twelve years after his initial efforts), he welcomed Dalhousie College's new Faculty of Pure and Applied Science as its founding Dean. MacGregor's successor as NSIS president, the civil engineer Martin Murphy (1832-1926), expressed appreciation that "at no time in its past history was our Institute of Science more assiduously cultivated than during the term of office of 


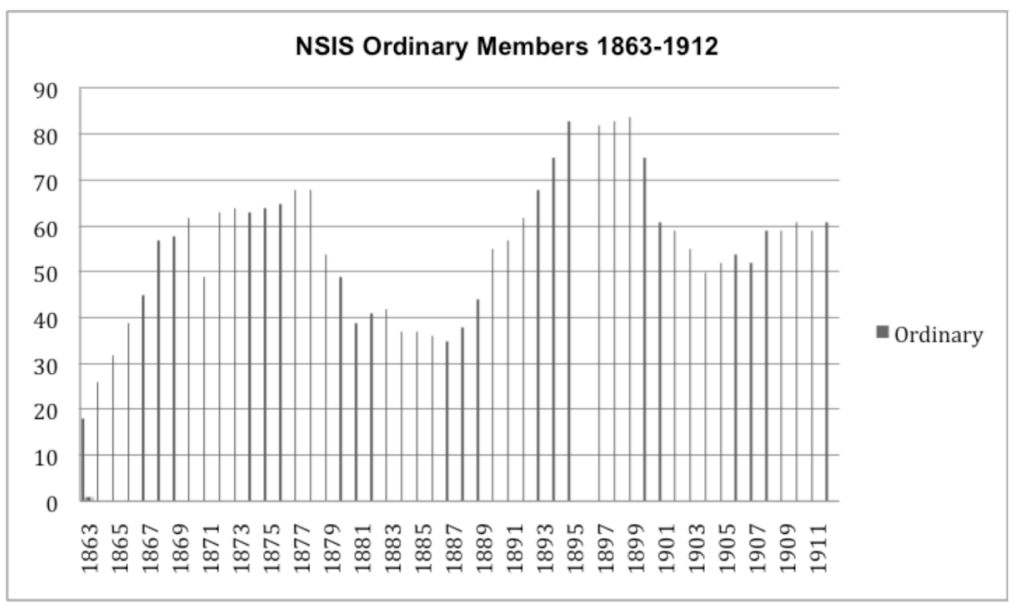

Fig 4 NSIS Ordinary Members, 1863-1912.

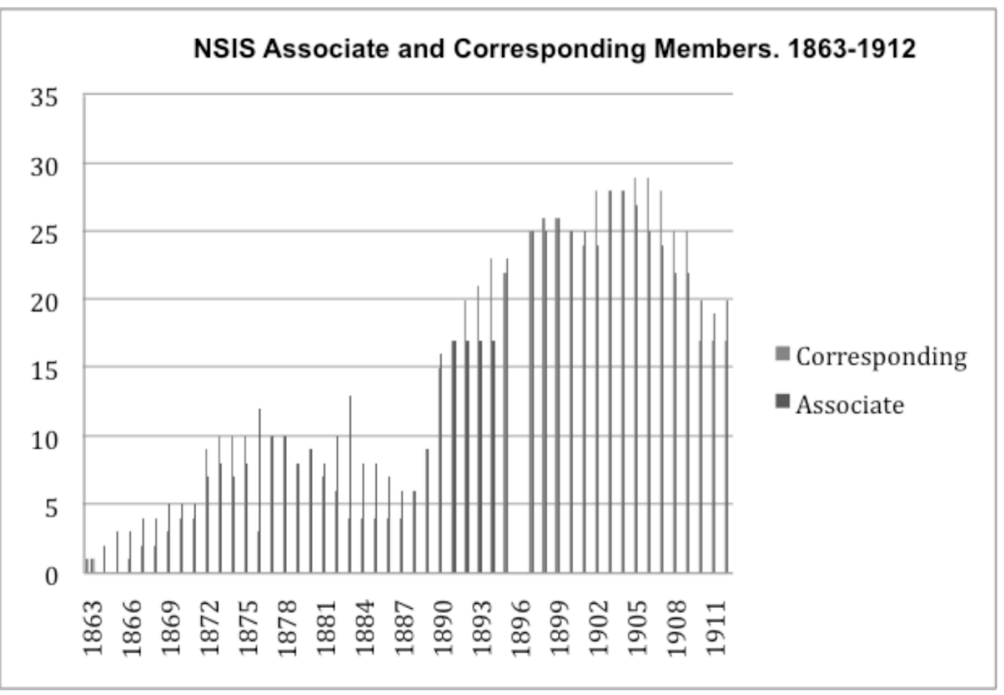

Fig 5 NSIS Associate and Corresponding Members, 1863-1912.

the late President; nor does his zeal end here: he is ever active for the promotion of its interests" (Murphy 1893:xlviii). George Lawson expressed similar presidential admiration in 1894: thanks to MacGregor, he acknowledged, "there is now no country under the sun whose scientific societies (where such exist) do not have our Transactions on their library shelves as exchanges for their own" (Lawson 1896:x). 
More than forty years later, MacGregor's name still evoked fond memories as the outstanding "young, auburn-haired, keen-eyed, vivacious and quick-witted" NSIS president ${ }^{13}$ (Piers 1936:200).

\section{Humboldtian Project}

MacGregor's sharp analytical instincts and organizational abilities also embraced a strong conviction of the timeliness of "collective scientific work," once inspired directly by the Humboldtian ideal and now epitomized by the (also Humboldt-inspired) British Association for the Advancement of Science [hereafter BAAS] (BAAS 1885; MacLeod 1981). He joined the BAAS for its Montreal meeting in 1884 , when NSIS members also hosted local excursions for overseas delegates who travelled through Halifax (Honeyman 1885). Of particular interest at that meeting was a joint BAAS-RSC resolution (framed by a BAAS committee that included MacGregor) to lobby the federal government for systematic tidal and current observations in Canadian waters ${ }^{14}$ (BAAS 1885:1xxiii; Lawson 1889:3). As the NSIS delegate to the RSC meeting the following year, MacGregor proposed an RSC committee to design a centralized programme of "simultaneous observations over the whole country" of various periodic natural phenomena, including bird migrations (MacGregor 1886b). As NSIS president in 1888, he reiterated his call for an RSC-administered programme of "collective investigation," citing a list of relevant subjects for which the NSIS could, in turn, serve as a regional coordinator. ${ }^{15}$ The timing seemed especially appropriate in light of MacGregor's overall plan to recruit observers by cultivating the interest and cooperation of science teachers throughout the province (MacGregor 1890a:189-190). When the RSC finally appointed a committee for this purpose in 1890 (MacGregor 1890b:iv; RSC 1891:xliv, xlvi; RSC 1892:1xiv), other favourable factors were also falling into place.

In 1891, George Lawson organized a Botanical Club of Canada under RSC auspices, with representation to be drawn from affiliated societies across the country. As its founding president, Lawson

13 The NSIS received a portrait of MacGregor in 1918 (NSIS 1919b).

${ }_{14}$ MacGregor also served on the RSC committee that reported some success in lobbying the federal government for this purpose in 1890; in that capacity he distributed printed circulars to maritime shipowners to invite their observations of tides and ocean currents (RSC 1891:viii-ix; Johnson 1891).

15 These included "the flowering of plants, the migration of birds, the movements of fish, the first appearance of insects," along with meteorological, geomagnetic, and tidal phenomena. 
envisioned the new society as the central clearing-house for a national "army of explorers" to collect seasonal floral data (Lawson 1892:20; RSC 1892:lxiv). As a botanist, he saw more clearly than MacGregor did, that new anatomical and physiological approaches at the cutting edge of the study of plants were critically diminishing the numbers of field workers emerging from universities. Like MacGregor, Lawson saw a potential solution in the growing numbers of science educators who could - along with their students - be recruited to form, in Lawson' charming phrase, a dedicated "band of gleaners" (Lawson 1892:19-20).

While Lawson and MacGregor lent their broader scientific vision to this Humboldtian project, it was the Botanical Club's first secretary, the Nova Scotia-born Alexander Howard MacKay (1848-1929), whose Herculean efforts lent it longevity with increasing analytical sophistication. MacKay had attended Pictou Academy and trained as a teacher before graduating with a BA in mathematics and physics (Dalhousie University, 1873) and a BSc in biology (University of Halifax, 1880). He joined the NSIS in 1885 while principal of Pictou Academy, where he renewed the science programme and established a provincial Summer School for Science to upgrade teachers in Nova Scotian schools. Elected an RSC member in 1888 as a field researcher of Nova Scotia's flora and fauna, MacKay moved to direct the Halifax Academy in 1889 before becoming Nova Scotia's Superintendent of Education in 1891. By introducing nature study into the schools as research experience for young students (Guildford 2003), MacKay was ideally positioned to carry out the phenological programme framed by MacGregor and Lawson.

The NSIS Proceedings and Transactions had regularly published separate Nova Scotian meteorological tables and floral and faunal lists. What distinguished the phenological programme undertaken by the Botanical Club of Canada was its interest in coordinating and correlating on a provincial, regional, and even national scale observations of meteorological and other physical phenomena, along with seasonal signals in the natural world, including first sightings of migrating birds and leafing and flowering plants. MacKay began in 1892 with a handful of observers across Nova Scotia and a single analytical innovation, listing days of the year by their ordinal values from 1 to 365 (Fig 6) (RSC 1891:xliv; MacKay 1893). A year later he added stations in New Brunswick, and began averaging dates by their ordinal values to calculate annual "normals" of the various phenomena 
NATURAL HISTORY OBSERVATIONS, NOVA SCOYIA, 1892. FIRST APPEARANCES DATED BY THE DAY OF YEAR.

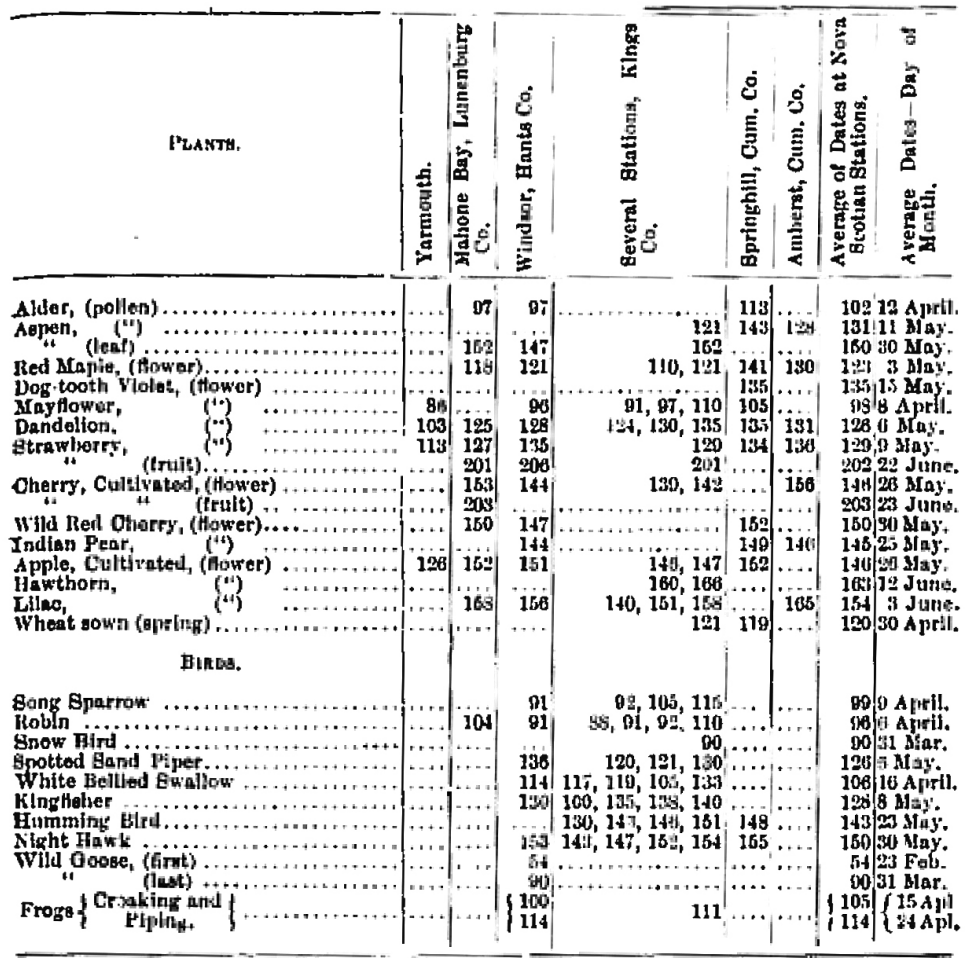

Fig 6 Natural history observations, made at several stations in Nova Scotia during the year 1892 (MacKay (1893):379).

under scrutiny (MacKay 1894). In 1894 he added a station in Winnipeg, and continued drawing "inductions" from the information that had begun to accumulate (Fig 7) (MacKay 1896a). In 1895 he added a Vancouver station, explaining that he had also inducted students to participate en route to and from Nova Scotian public schools, with teachers submitting tabulated results in 100 (and eventually 200) categories. MacKay reduced these tables to an overall analytical picture that, he believed, sharpened with every additional observer at every additional station (Fig 8) (MacKay 1896b).

MacKay recognized the composite image taking shape before him as an increasingly valuable climatic record with both historical and geographical dimensions. His calculated "normals" revealed patterns of continuity and change across time and space, demarcating ten "meteorological or biological regions" across Nova Scotia, where 


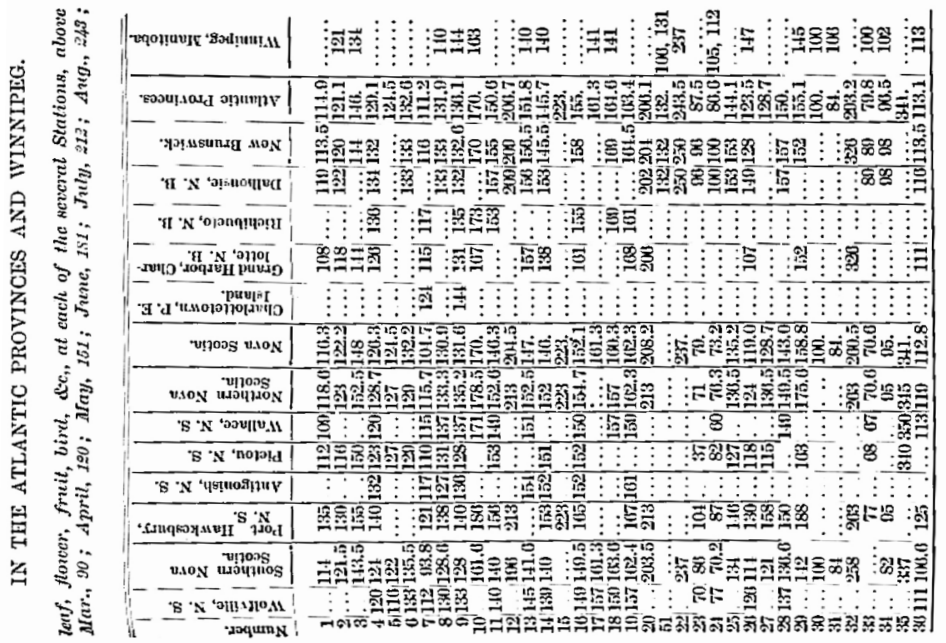




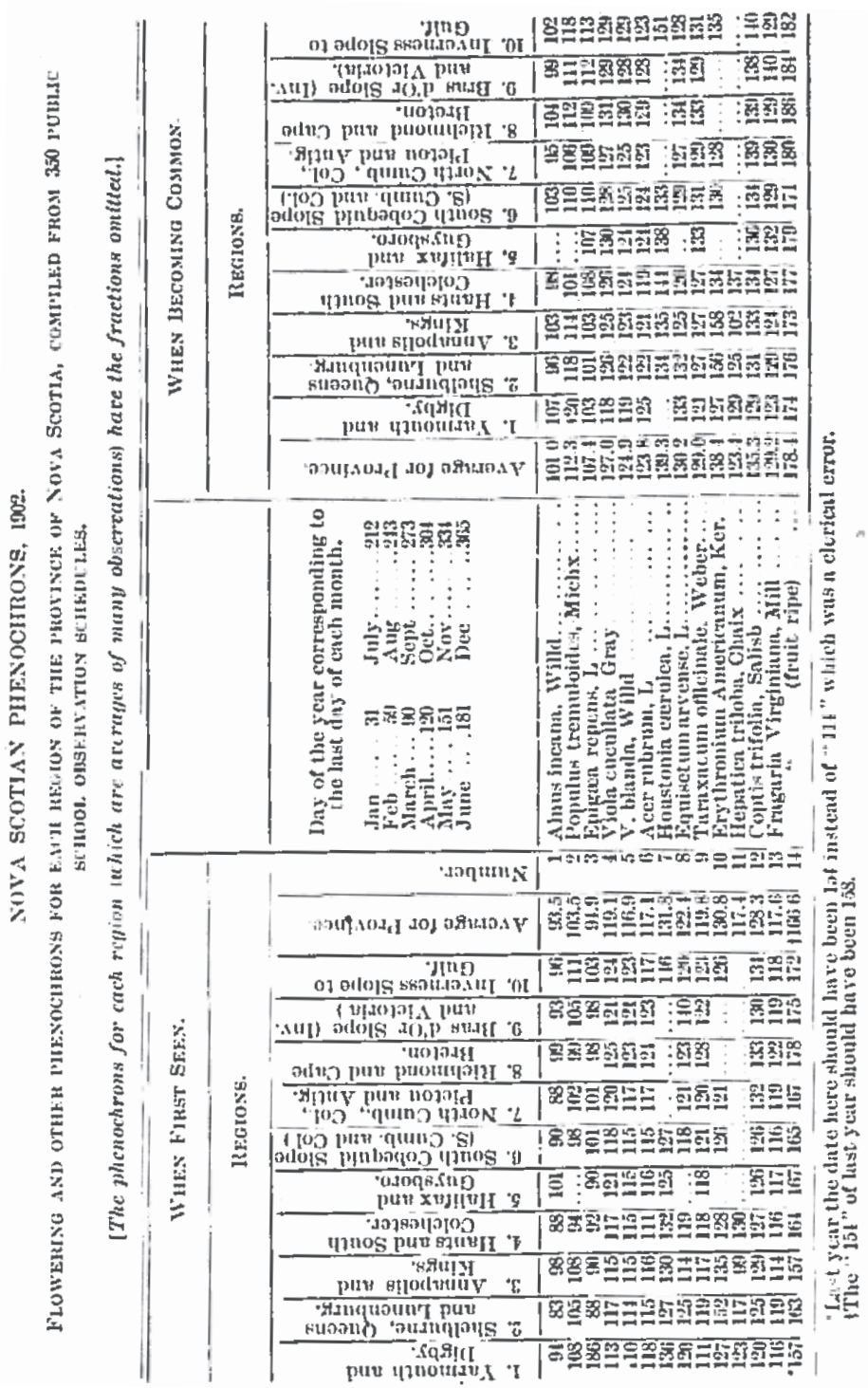




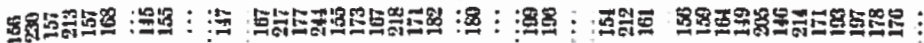
可策

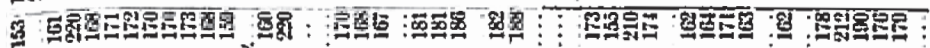

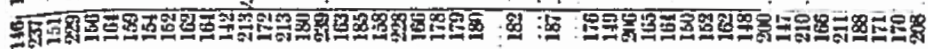

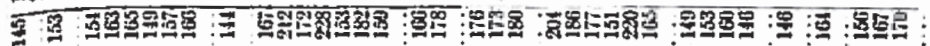

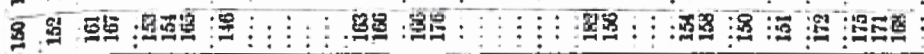

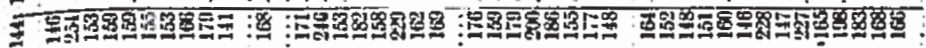
三

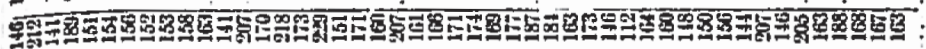

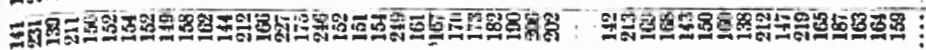
D.

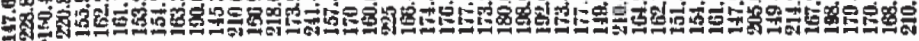

S

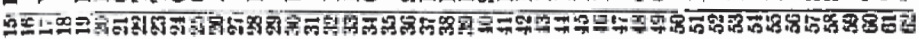

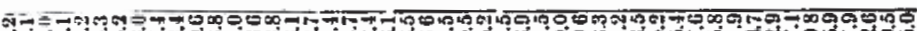
揭

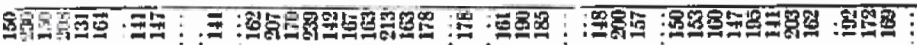

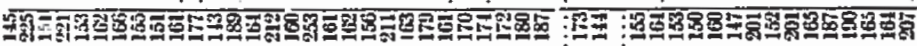

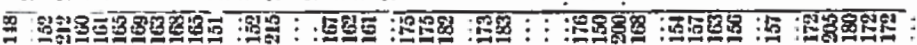

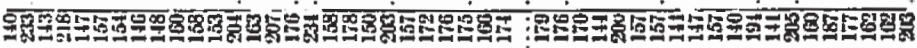

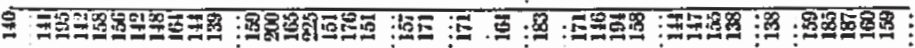

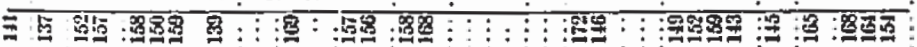

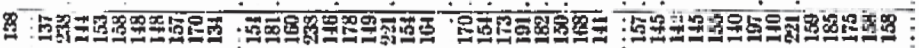

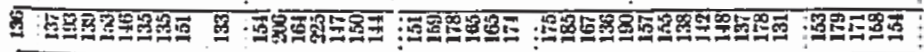

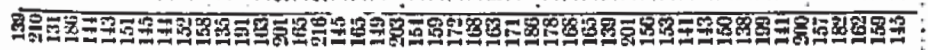

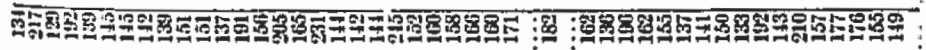


he had the greatest number of observations to work with. He called his calculated mean dates of seasonal occurrences "phenochrons," which he tabulated and then duly graphed and mapped in search of additional "inductions" (Fig 9) (MacKay 1897; Mackay 1899; MacKay 1905:145). By 1899 he was processing reports from 725 Nova Scotian school districts, along with thirteen stations across the rest of the country through the RSC's affiliated societies. Besides the mean values that MacKay calculated over several years, he ran his phenochrons through specific geographical regions as the data - now including seasonal animal sightings, storms, and agricultural activities (Fig 10) - accrued from year to year, and added earthquakes after one rocked the province in 1904. MacKay's project reached an interpretive peak in $1910^{16}$ as he mapped the geographical patterns of seasonal changes across Nova Scotia, identifying "slopes" and "belts" that subdivided the province's climatic regions into zones (Fig 11). Despite declining numbers of student participants thereafter, the observations continued in Nova Scotian schools until he retired in 1924 (MacKay 1900; MacKay 1902a; MacKay 1905b).

MacKay housed both the voluminous tabulated submissions as well as his own meticulous compilations at the Provincial Museum. His pioneering analytical methods, derived from his training in physics, inspired similar projects in Britain, Germany, and Denmark (MacKay 1903:488). As "the world's largest database of its kind," the project earned renewed scientific recognition during the 1990s as "an important benchmark for assessing climate change" (Fenech 1999; Austen 2000; Guildford 2003; Fenech 2005; Zwarenstein 2010) and a revival by Nova Scotian students in the Thousand Eyes Project. ${ }^{17}$

\section{Parting Ways}

For all that MacKay's labour-intensive phenological programme continued well into the 1920 s, it represented, in its close ties to place, the exception rather than the rule of science in its day. In 1902 he himself recognized a bitter irony in the fact that the NSIS's "audiences have been worldwide, but not local" (MacKay 1905a:v). Indeed, the research ideal reflected in MacGregor's influence upon the Institute had, by the 1890s, seen Analytical Ways of Knowing superseded by

${ }^{16}$ MacKay had by then taken on other heavy responsibilities: head of the new Department of Technical Education (1907); editor of the NSIS Proceedings and Transactions (1908); and NSIS Council member and president (Guildford 2003).

17 http://suite101.com/a/thousand-eyes-project-a206984. 


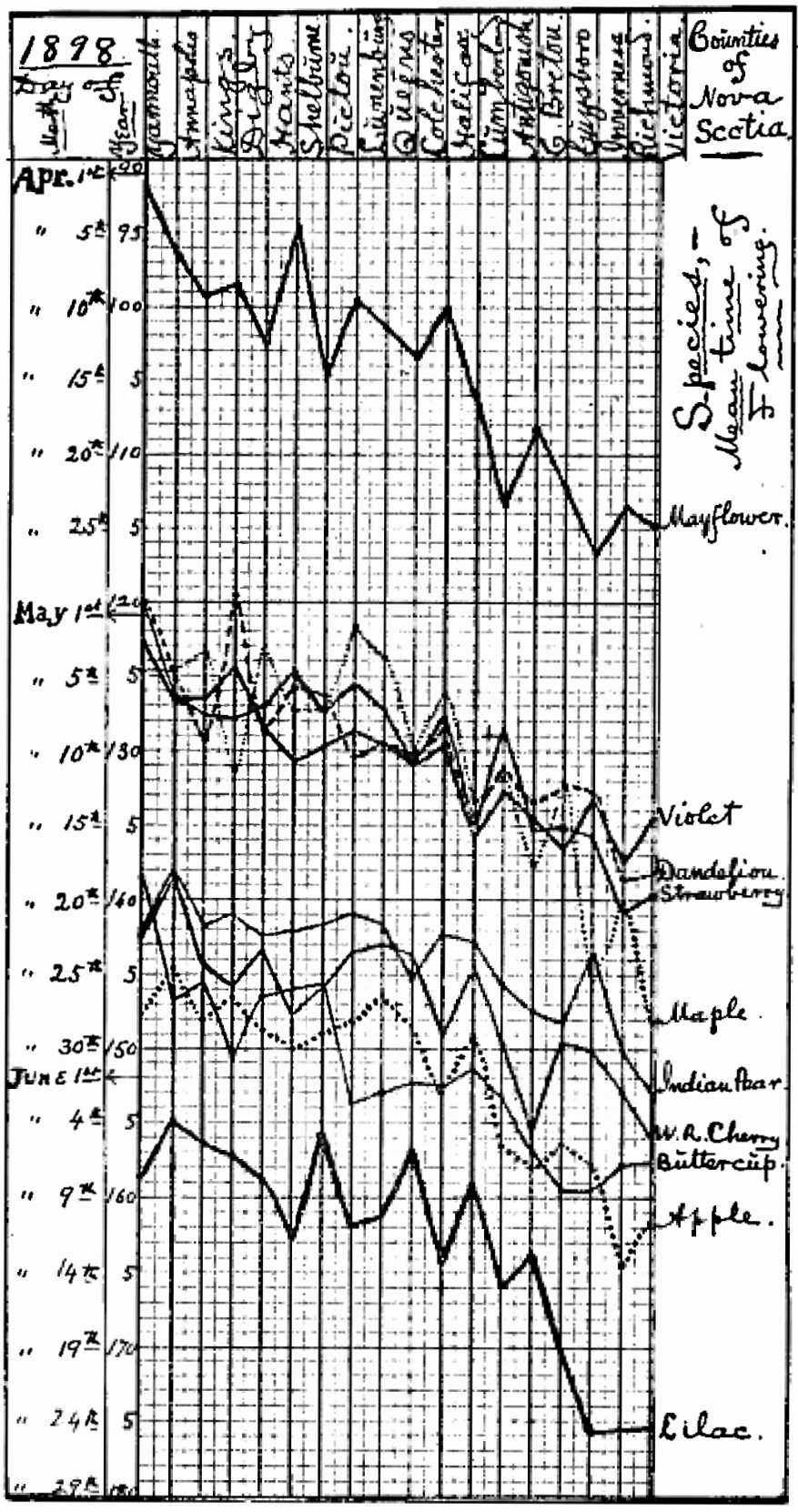

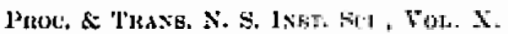

THAsis. $\cdots$.

Fig 9 Phenochrons for 1898 (MacKay (1899):97). 
CANADIAN PHENOCHRONS, 1902.

Uhgenvation Stationg-When Firgt Sies.

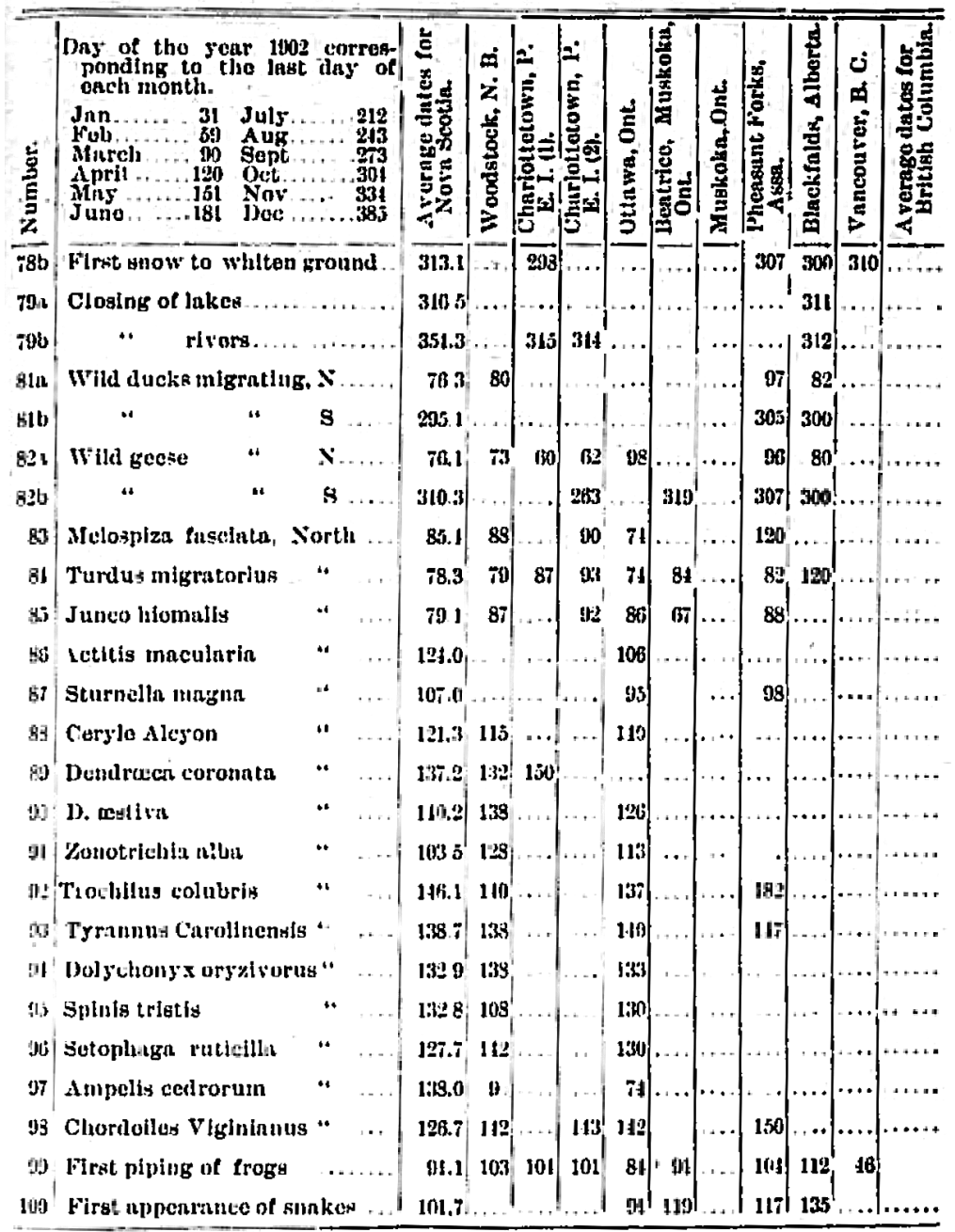

Fig 10 Phenological observations in Nova Scotia and Canada (MacKay (1905b): 157). 


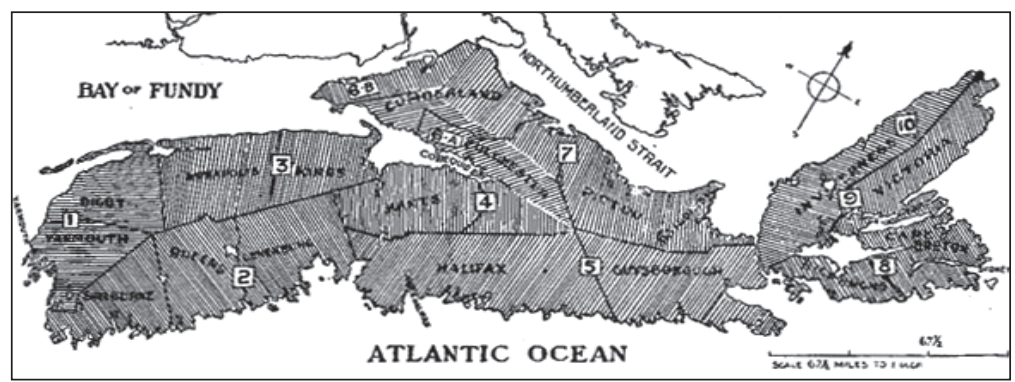

Fig 11 The Ten Phenological Regions of Nova Scotia (MacKay (1912):178.

Experimentalist Ways of Knowing,$^{18}$ with new emphasis on the laboratory as the site for cutting-edge knowledge production (Pickstone 2001) especially in new interdisciplinary fields such as biochemistry and atomic theory (Fergusson 1915).

From their respective influential vantage points, Lawson, MacGregor, and MacKay not only promoted advanced science teaching in Nova Scotia through firsthand laboratory experience, which Lawson recognized as "a great, if somewhat silent change" in the universities (Lawson 1888:xxiii). MacGregor and MacKay also worked to bring the laboratory experience into Nova Scotian secondary schools. While the similarly named educator and administrator Alexander McKay's (1841-1917) presidential address in 1898 expressed regret that, despite these efforts, "experimental work [seemed] almost wholly neglected" there (McKay 1899; Yorke 2003), his superior, AH MacKay, reported progress on this front only three years later: "Throughout the province several of our county academies or high schools have better laboratories for proper science teaching than had our best colleges not many years ago; and some of the teachers are more competent than many of the good old college professors" (MacKay 1902b).

In the same address, however, MacKay recorded the NSIS's mixture of pride and regret at MacGregor's recent departure from Halifax, to succeed PG Tait in the prestigious Chair of Natural Philosophy at the University of Edinburgh. MacGregor's reputation as "a very expert experimental investigator" included recognition that "with his skill and ingenuity he made anything into apparatus, and made a little go a long way, and made it give him precision too," under physically

18 Experimentalist Ways of Knowing aimed to "transform" nature (Wynn 2007: Part 5) through synthesis and invention, predominantly in the laboratory (Pickstone 2001: Part 3). 
challenging conditions that put later, better-equipped generations to shame (NSIS 1919b:Ixxxii). A measure of MacGregor's achievement through the NSIS in this regard may be found in the fact that when he had applied to succeed Alexander Johnson (1830-1912) in McGill University's Chair of Natural Philosophy in 1890, McGill instead preferred a candidate trained in the older Cambridge mathematical tradition ${ }^{19}$ (Gingras 1991:20). At Edinburgh a similar struggle to introduce laboratory work into science teaching preoccupied MacGregor for the rest of his career, and may have helped to cut it short (MacKay 1902b; MacGregor: a Scottish tribute 1913; Knott 1913). His unexpected and untimely death of heart failure in 1913 quite naturally intensified the retrospective mood that marked the end of the NSIS's first half-century.

\section{HEADWINDS}

Among recurrent themes, an essential tension between theoretical and utilitarian goals ${ }^{20}$ - between specialized and general interest - in science, which had characterized the NSIS since its founding (Lawson 1896:x-xi), remained a source of concern. One repeated response was to offer the kinds of popular lectures that attracted large audiences in other jurisdictions (MacGregor 1890a:190-1; MacKay 1905a:v; Mackay 1912a:vii; Bishop 1912:xxv). Yet neither these efforts nor the admission of women as Ordinary members from 1895 substantially increased NSIS numbers (NSIS 1896:xvi). The longstanding problem of the NSIS's inaccessibility to members who resided outside of Halifax also found a hopeful response in the establishment in 1901 of an offshoot centred at Acadia College in Wolfville; in this first iteration, however, the group ran out of steam by 1904 (MacKay 1902b:Ixxxviiilxxxix; Haycock 1902; NSIS 1908:ix; Piers 1915:lxxiv). Besides the palpable effects of the RSC, the appearance of specialized regional professional societies, including the Mining Society of Nova Scotia (1892) and the Nova Scotia Society of Engineers(1906), also continued

19 MacGregor's innovative abilities in studies of ionization theory (much like those of Ernest Rutherford in atomic theory at McGill a few years later) rested with his affinity for laboratory apparatus; in contrast to his authoritative confidence on this front, he believed that his own mathematical insight and training were inadequate (MacGregor: a Scottish tribute 1913:5-6; Mackenzie 1913:1xxxii).

${ }^{20}$ AH MacKay traced this dichotomy back to the difference between ancient Greek and Egyptian outlooks on nature, respectively (MacKay 1902b:1xxxix-xc). 
to chip away at NSIS memberships as well as at the Proceedings and Transactions (Mackay 1912a:iii; Bishop 1912:xxiv; Piers 1915:Ixxiii).

MacGregor had, furthermore, opened the vexing question of how to meet the skyrocketing costs of laboratory research. His RSC committee report in 1885 recognized "private beneficience" as the only realistic source of funding in a world of cash-strapped public institutions (MacGregor 1886a:xli) whose leaders had hardly begun to imagine taxation levels on the scale of scientists' rapidly growing wish-lists. When the Royal Society of London invited financial contributions to its Victoria Research Fund in 1897, the NSIS regretted that, since Nova Scotia's "industries have not yet reached the stage in which the advantages of scientific research become manifest," it could do no more than pass the word along to those in a better position to offer funds (NSIS 1897). As the need for laboratory equipment intensified, it was all the NSIS could manage to offer grants of $\$ 25-\$ 50$ to scientific research students in 1912-13 (NSIS Council Minutes 1912:18 July and 4 October; NSIS 1915:xlvi). Moreover, it was also becoming painfully apparent that the "collection of partially catalogued, somewhat inaccessible reports of scientific societies" that resulted from the NSIS exchanges could hardly "be said to constitute such a scientific library as the majority of workers need, however useful it may be to those engaged in original research" (McKay 1900:xxxviii). What little hope there was of government support for research focused on projects initiated by the BAAS and other external influences. In response, NSIS members worked to get Nova Scotian scientists and students actively involved in the federally-funded Marine Biological Laboratories that began work along the Atlantic coast in 1899 (MacKay 1902b:xcvi-xcvii; MacKay 1905a:iv-v; Hubbard 2006:chapters 1-2).

\section{A. Industrial and/ or Conservationist Research?}

With government funding even for existing projects in such short supply - the loss of the NSIS provincial government grant (apparently in an oversight) in 1907 turned out to be anything but temporary - the achievements of full-blown industrial research in both Germany and the United States soon illuminated the NSIS's horizon. In 1906 NSIS president FWW Doane explained how "some of the best research work of to-day is being guided by business corporations," assuring his audience that the "purely scientific spirit" continued to guide scientists so engaged (Doane 1908:v). Two years later Ebenezer Mackay, Dalhousie's first honours graduate in chemistry (1886) and a research 
$\mathrm{PhD}$ from Johns Hopkins University, interpreted (again overly optimistically, as it turned out) Nova Scotia's Technical Education Act in 1907 as an indicator that "the value of research work is appreciated in industrial circles," so that "our Institute, no longer obliged to go into the highways and hedges in order to compel men to come and fill up its programme, will be embarrassed with the wealth of papers at its disposal" (Mackay 1912a:l-li). MacKay's presidential address in 1910 minced no words regarding the decisive role of science in a modern industrial society. After explaining recent achievements in the chemical synthesis of organic compounds, especially in Germany, ${ }^{21}$ He warned his NSIS audience that:

It requires no prophet to foretell the conclusion of the story: the industry of indigo production [and with it the production of chemical dyestuffs, fertilizers, explosives, and other crucial hydrocarbon-based syntheses] will pass from the banks of the Ganges to those of the Rhine. And the moral is equally plain. It is the country that is most successful in making science not merely the occasional adviser of the industries, but their ally and confidant, that will be victor in the contest for industrial supremacy (Mackay 1912c:xviii).

On a competing front, as time would soon confirm, the role of science in the conservation of Nova Scotia's natural resources, especially its forests and fisheries, also took on new urgency. Ever the activist, AH MacKay used his role as Nova Scotian vice president of the Canadian Forestry Association to facilitate a joint meeting with the NSIS in 1904 (NSIS 1906), followed by the appointment of an NSIS committee on forestry. MacKay served an analogous role on the board of the Marine Biological Laboratories, whose mandate he interpreted in terms of research to conserve the Atlantic fisheries (MacKay 1902b:xcvi-xcvii; MacKay 1905a:iv-v). Ebenezer Mackay followed up with the force

${ }^{21}$ In 1909 Mackay also cautioned his NSIS audience that recent "epoch-making work" in atomic theory did not yet justify the "evil consequences" of assuming atoms' actual existence. Ernest Rutherford's recent announcement, however, "that he had obtained a direct experimental proof of the existence of atoms" led Mackay to concede that perhaps "atomic theory, unlike the systems that have had their day and cease to be, is to abide with us as a permanent utility" (Mackay 1912b). The NSIS Proceedings and Transactions were already publishing papers on experimental research in Dalhousie University laboratories on radiation. 
of his presidential cudgel in 1908, calling the NSIS to public service on these important issues as its natural responsibility:

Where important natural resources are being wasted, it is the duty of a scientific society such as the Institute to do all in its power to arrest the evil. The Institute is the only scientific society in the province and as such should be the official exponent of scientific opinion. It should be able to create what may be called a scientific public opinion powerful enough to make itself felt. It is as true now as in the days of the wise king that "Where there is no vision the people perish." In such a case as the present, it is for men of science to supply ${ }^{22}$ the lack of vision (Mackay 1912a:li-lii).

In the same vein, Mackay called upon the NSIS to sound the clarion call of "enthusiasm" to engage farmers, fruit-growers, fishermen, and others who worked on the scene, as early-warning observers of infestations and related conservationist issues (Mackay 1912c:v-vi). For all that Sir Wilfrid Laurier's Liberal government's establishment of the Canadian Commission on Conservation in 1909 represented an encouraging initiative, the Commission's mere fact-collecting powers, argued a far-sighted DB Fergusson in his 1913 presidential address to the NSIS:

Could be vastly extended to providing endowment for research and founding establishments like the Kaiser Wilhelm Institut in Germany. If civilized nations could see the absurdity of settling ethical issues by destruction of cellular tissues, large sums of money would be available for research into conserving the national resources which we use at present, and tapping those going to waste around us. We might then feel less ashamed of what future generations will think of the manner in which we squander their birthright of mine, field and forest (Fergusson 1915a:cxxi-cxxii).

${ }^{22}$ Mackay's use of the word "supply" here, as in filling a gap, has gone out of fashion and suggests the opposite of his meaning. 
The NSIS thus entered the $20^{\text {th }}$ century with some forewarning of what its second fifty years might bring, but no inkling yet of how deeply some longstanding assumptions would soon be called into question. A comparative "wealth of facilities" had not kept up, let alone surpassed, "the output of the old strenuous days when we met in the poorly lighted, badly seated, and primitively warmed and ventilated museum" where its 24 founding members had first assembled. A periodic pruning of membership lists when payments fell into arrears also showed Ordinary memberships tending downwards to about 75, raising questions about how best to assess the real state of the Institute's well-being (Mackay 1912c:ii-iii). How, then, to continue its struggle to nurture "the development of the scientific cult of to-day" (Bishop 1912:xxiv) in the face of an increasingly splintered constituency (Mackay 1912c:v)?

Recurring NSIS tensions between aims and audiences - between the determination to publish original scientific work and the wish to engage as many Nova Scotians as possible - intensified with the unprecedented series of international crises that plunged the Institute - along with the rest of the country - into war, economic instability, and war again. While the force of circumstance limited available options, the Institute continued its efforts to navigate between the Scylla of falling behind the science of the times, and the Charybdis of becoming irrelevant to its place of origin.

\section{B. Forced Hands}

The outbreak of the Great War in 1914 altered important conditions under which the NSIS operated. Without its provincial government grant, the Institute faced increasingly dire financial circumstances in a situation about which it could say or do very little. Exchanges with most of Europe also ceased abruptly. The war not only curtailed important European research; it also cut off from North American research and industrial production indispensable chemical products under German monopoly, including potash, synthetic dyes, and even precision glass for periscope lenses (Fergusson 1915b:iv-v; Fergusson 1916:xvii-xix).

Like other scientists elsewhere, the NSIS soon forged its initial shock at the grave results of Allied failures to heed its earlier warnings, into hope that the British and Dominion governments' rude "awakening" to "the value of science and scientific research" would at last become "complete and permanent" (Fergusson 1916:xvii-xix; 
NSIS 1916:xxiii). The establishment in 1916, after German poison gas attacks on the front had begun, of British and Canadian Honorary Advisory Councils for Scientific and Industrial Research led DF Harris to assure the NSIS in his presidential address that year that:

Appalling beyond human comprehension as are the evils of this insanest of all wars, yet it cannot be denied that some measure of good is emerging distinctly from the welter. It is not too much to say that for the first time in the history of the British Empire, science is coming into her own. It is no doubt humiliating to have to confess that it was the misapplied science of our enemies which demonstrated to us how inferior was the place we had given science in our own national life. The land that produced Roger Bacon, Napier, Gilbert, Harvey, Newton, James Watt, Jenner, Faraday, Darwin, Kelvin, and Lister had to be shown by the exponents of science prostituted that science was nevertheless worth cultivating for its own sake (author's italics; Harris 1918:xxxvi).

In practice, however, an NSIS suggestion to the Minister of Militia and Defence in response to Canada's Military Service Act in 1917, that "technically trained men as may be enlisted be drafted into that particular branch of the service for which they are most nearly fitted by their training and experience in civil life," elicited little more than polite assurances of "due consideration" (NSIS 1919a:lxx). War's end brought a more militant NSIS resolution that, "with a view to the future protection of the Canadian chemical industry" and "before the signing of peace," the federal government ought to "empower a Canadian foundation company to control enemy patents registered in Canada" (NSIS 1919c).

Wartime also left its imprint on the NSIS's regular routine. Research papers for presentation dwindled to a trickle, raising suggestions once again about offering popular scientific lectures, at least to wait out the storm (NSIS Minutes: 28 March 1918). While members had by 1914 already noted such a predominance of papers in physical sciences that presentations in other fields "met with a hearty welcome" (Fergusson 1915b:ii), this trend persisted well into the postwar years, with research on the production of synthetic dyes and potash, and mapping 
Nova Scotia's distribution patterns of naturally occurring chlorine as “isochlors"(Creighton 1919; Vickery 1919; Whyte 1921; Munro 1923).

Moreover, discussions about whether to continue limiting the Proceedings and Transactions to Nova Scotian topics whenever possible resulted in a 1917 resolution that the publication be open only to scientists working in Nova Scotia (NSIS 1919a:lxx-lxxii). As Murphy's Law might have it, an interesting dilemma resulted with the arrival in 1919 of a paper from a longstanding Corresponding member, Major JH Barbour (1873-1944) of the Royal Army Medical Corps (stationed in Halifax, 1903-1905), who had managed to botanize during his wartime service in the French countryside and now offered a paper on the subject for comparative purposes. The upshot, after the NSIS Council agreed to read the paper at the next Ordinary meeting, included formal decisions to give priority in the Proceedings and Transactions first to the natural science of the maritime provinces and, secondly, to other scientific work by "active members residing in Nova Scotia," 23 and thereby to decline to publish Barbour's paper (NSIS 1919a; NSIS Minutes 2 January, 8 November, 13 October 1920).

\section{Boom and Bust}

The return to peacetime in 1919 lent old themes new twists. Inflation meant rising costs, labour disputes, and a level of financial concern for the Proceedings and Transactions that forced the NSIS to consider publishing only abstracts of papers presented at its meetings. It also emboldened successive NSIS Councils to remind the provincial legislature that its annual grant had fallen by the wayside in 1907, and never been restored. On that front it finally succeeded in 1927, regaining sufficient funds to update the Provincial Science Library but leaving the Proceedings and Transactions to cut back pages if more revenues could not be secured (Johnstone 1928:xxii).

It is difficult to assess precisely the war's impact on NSIS memberships, because during that time annual lists were not revised to remove names with unpaid dues. While Ordinary memberships began once more to climb noticeably in 1919 (NSIS 1920:xxi; NSIS 1921:xxix), Corresponding memberships took longer to recover, then declined

${ }^{23}$ Barbourhadbeen stationed in Halifax, 1903-05: http://www.bonhams.com/auctions/20810/ lot/245/, accessed 30 March 2014. This criterion was widened again in 1926 to put the onus on the Council, so that any paper read first before the NSIS could be deemed eligible to appear in the Proceedings and Transactions (NSIS Minutes of Council 1 November 1926). 
precipitously during the Great Depression of the 1930s (Fig 12) (King 1940:47): the Council resolved as late as 10 April 1922 not to resume exchanges with Russia, Germany,Austria, and Hungary for the time being. It amended this decision on 4 December 1923, restoring German, Austrian, and Hungarian societies to the NSIS mailing list (with the Recording Secretary, Harry Piers, dissenting) but deleting all Russian [now Soviet] institutions.

The decisive factor during this period was the establishment of the National Research Council of Canada [hereafter NRC] as a permanent institution in 1923, with its Canadian Journal of Research following in 1929. The NRC entrenched Experimentalist Ways of Knowing in Canada (as happened elsewhere) more deeply than ever during the 1920 s and 30s, to the point of denying federal funding for natural science fieldwork in favour of applied and especially industrial research (Ainley 1988). A continuing chronic shortage of research papers dismayed the NSIS as a failure in its "chief aim" (NSIS 1923:I; Ritchie 1926a:xxxi), with the Council asking its members to report "the results of all scientific work they might be engaged upon, to be published in abstract, or in some cases in full." Despite some success, the editors of the Proceedings and Transactions made frequent adjustments in order to carry on - not only against increasingly numerous specialized competitors, but also in the face of printers' strikes, fires, and lost papers that delayed issue after issue during the 1920s, through no fault of the Institute - but inclining potential authors even less to submit papers (NSIS 1926b:xxiv-xxv; Ritchie 1926b:viii; McIntosh

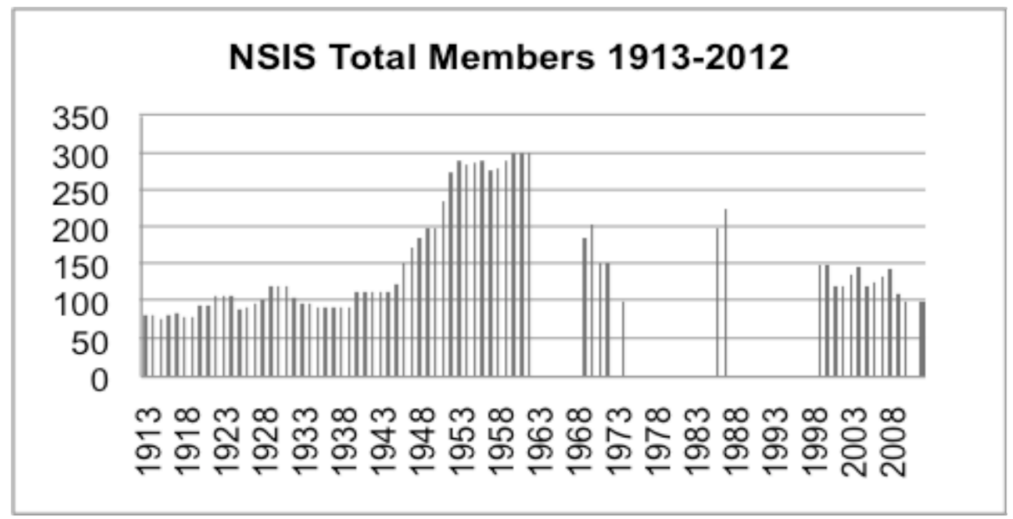

Fig 12 NSIS Total Membes, 1913-2012. 
1929:xxxv; (Nickerson 1925:xx; Johnstone 1927:xiii; McIntosh 1929:xxxiv-xxxv).

A committee first appointed in 1919 to identify ways to "further the cause of science in a more popular and general way" (NSIS 1920:xxi) became a kind of ad hoc standing committee during the 1920s, reappointed annually to develop new ideas. The first, an annual series of popular science lectures that sometimes attracted large audiences, challenged the NSIS to learn both to advertise its activities more effectively as well as to balance its programme with both physical and biological sciences if it hoped to remain the "tremendous factor in the scientific, industrial and economic development" of Nova Scotia that it seemed to have been in JG MacGregor's day (Nickerson 1925:xx; NSIS 1925; NSIS 1926a:xxii; Ritchie 1926a:xxxi, xxxiii).

The 1926 committee, still dissatisfied with attendance, hit upon the idea of organizing a science exhibition "to stimulate a more widespread interest in pure science and it's [sic] possibilities." With cooperation from the local universities, the College of Pharmacy, the Technical College, and the Atlantic Experimental Station for Fisheries - and support from the local radio station and public transportation - the resulting exhibits and demonstrations succeeded "beyond the expectations of its promoters" in attracting at least 4500 visitors, leading the NSIS president to dream wildly of tripling memberships to "at least 300" (Johnstone 1927; NSIS 1926c). A still larger exhibition in 1928 attracted corporate sponsors and 6000 visitors, leaving its harried NSIS organizers (although not the NSIS executive) unwilling - with expenses of \$26.35 to pay from NSIS funds - to plan another such event (NSIS 1929a; McIntosh 1929:xxxv-xxxvi; McIntosh 1932: 15; Leim 1935:287). Nor did the remarkable power of scientific demonstrations to attract larger audiences go unnoticed in these experiences (Henderson 1939b:25).

With new memberships during these years nevertheless stemming not from the general public, but rather from new colleagues in Nova Scotian universities, the NSIS president in 1929 reiterated its grand aim "to have in its Transactions a record of all original work done in Nova Scotia." Opening up the prospect of occasional meetings outside of Halifax, the Council sought to engage Associate members to report "any work of a scientific nature of provincial importance" in their respective institutions. It also inaugurated Student memberships (at reduced cost and without a vote) in 1930, adding 21 original 
Student members ${ }^{24}$ to an overall list that continued to hover around 100 (McIntosh 1929:xxxv; NSIS 1932:17; Young 1933a:68-69; Young 1934:215-216).

It was on behalf of its research-oriented constituents that the NSIS now played down popular lectures, instead undertaking two new endeavours during the 1930s. In 1934 it came to the Council's attention that the new Union List of Scientific Serials in Canadian Libraries cited no Canadian libraries east of Montreal. An NSIS survey of regional libraries for lists of their scientific periodical holdings became the basis, with NRC funding, for the NSIS's Catalogue of Scientific Periodicals in the Libraries of the Maritime Provinces (1936) ${ }^{25}$ (NSIS Minutes of Council: 29 January, 12 February, 30 April 1934; 22 April, 30 September, 9 October 1935; 13 January 1936; NSIS 1938:287; NSIS 1936b).To attract more research papers, the Institute in 1937 also began offering travel funds for presenters from outside of Halifax (Henderson 1939a:441).

In response, one member's resignation in 1934 to protest the NSIS's heavy emphasis on original research once again opened the familiar chasm that the Institute could never really close. A set of resolutions reaffirming the principles of open discussion in the Institute's mandate silenced an open disagreement over what level of questioning constituted "fair play" toward papers that some members deemed not sufficiently original or scientific (NSIS Council Minutes: 9 October 1934, 30 September 1935). Not far behind festered a long-simmering chagrin articulated by Harry Piers, by then one of the oldest NSIS members and still Recording Secretary, that - despite a recent rise in research papers on biological topics (Young 1934:216) - papers "on the lines of natural history or faunistic work" in Nova Scotia that should "logically" be sought out for the Proceedings had instead become rarities on NSIS programmes. Moreover, a revealing Council discussion across two committees in 1931 seemed, in typical Experimentalist form, to equate natural history with a dilution of "real" science better suited to an occasional popular lecture ${ }^{26}$ (NSIS Minutes of Council 1931:26 October, 5 November; Leim 1935:286).

${ }^{24}$ Scientific research could be dangerous work: while it was bad enough when one NSIS member drowned while conducting biological research in the Gulf of Mexico in 1929, it was even worse when an original student member was killed in a chemical laboratory accident two years later (NSIS 1929b; NSIS 1932b).

${ }^{25}$ Future supplements of the Union List no longer ignored maritime libraries (NSIS 1963:203).

26 This assumption was repeated in the NSIS Council meeting on 13 November 1950. 
After repeated presidential rebuttals that the apparent disappearance of natural history:

Is the fault, not of the officers or council, but of our naturalists. It is hardly necessary to say that contributions from them will be welcomed in the same spirit as those received from our physicists or chemists (McIntosh 1932:15; see also NSIS Minutes 1930:8 December).

Piers utilized his own Presidential Address in 1936 to offer "Suggestions for Future Revisional Work in the Natural History Field." Citing recent examples, he noted in particular "the present need of thoroughly revised or new working-lists of our fauna and flora," especially "in the light of recent additions as well as progress in nomenclature" to which Nova Scotian fieldwork still had important contributions to make (Piers 1938:283-285).

The NSIS decision to mark its $75^{\text {th }}$ anniversary in 1937 by inviting the NRC president, Major-General AGL. McNaughton (1887-1966), to address the Institute on "The Organization of Research in Canada" instead reaffirmed the deeply entrenched order of the day: science meant laboratories, research meant industrial efficiency, and Soviet Russia's state-driven industrial applications of science now seemed to offer the shining example of the way forward for Canada. "If we fall behind in the struggle" to keep up, McNaughton warned an audience of about 250 people, "we face disaster just as certainly as did the tribal peoples of early history” (McNaughton 1938;218-220, 223, 228-231).

\section{Unexpected Ironies}

McNaughton's military swagger, forged in the bitter lessons of the Great War's darkest days and continued as he fought bitterly to secure federal funds for NRC laboratories, found renewed power as Canada entered the breach once more in 1939. What one NSIS president called "the crazy, screaming vortex of a global war" reaffirmed the need for constitutional amendments to NSIS by-laws to ensure flexibility "to meet changing conditions" (King 1941:48; Bean 1946:4). This time, membership numbers - even with new potential among Halifaxstationed servicemen - fell steadily as NSIS members were seconded for government service, assigned to overseas military service, or, still worse, killed in action. Shattering once again the Institute's hard-won exchange networks, total war also altered once again the balance of 
research topics as nothing else could do, this time imposing blackouts on presentations in physics, chemistry, and the fisheries because of their strategic importance. The result was fewer papers overall, but a greater proportion in biology and related fields, with growing interest in genetics as "the most outstanding feature in the development of biology during the present century" (Gates 1941:127; King 1941; Bean 1942:291; NSIS 1942).

Regional research facilities and their staffs and students multiplied after war's end in 1945, boosting NSIS memberships and attendance at meetings to unprecedented heights. These positive developments were especially "interesting," as the NSIS president, FR Hayes, observed in 1946:

In view of the complete absence of innovations designed to make the Institute into more of a social organization, or to dilute or popularize its scientific reports. Living as we do in the golden age of advertising, it is a matter of satisfaction to discover that an organization can flourish when it has nothing to offer except solid worth (Hayes 1948:13).

In particular, the Institute welcomed the Defence Research Establishment Atlantic (DREA) in Dartmouth in 1944, which became part of the national Defence Research Board in 1947; the Nova Scotia Research Foundation in 1946, which absorbed some of the burden of maintaining and expanding the Provincial Science Library; the Faculty of Graduate Studies established at Dalhousie University in 1949; and the NRC's Atlantic Regional Laboratories in 1952, all raising high hopes that NSIS membership numbers would rise accordingly. By 1948, much hard work had also restored prewar levels of NSIS exchanges. This postwar optimism reaffirmed the value of the published Proceedings, ${ }^{27}$ despite ongoing challenges sustained by their dedicated editors; and of fully integrated NSIS meetings, despite informal calls once again for sectional divisions with separate - and perhaps even concurrent discussions of ever more specialized research topics (Coffin 1950:37; Weld 1951; NSIS Minutes 1952: 20 October; Weld 1953; Dingle 1962). As one president wondered, were these grumblings not "expecting too much of such an Institute as ours in an age when it is becoming

27 "Transactions" had been dropped from the title with the appearance of Volume 19 in 1935. The Proceedings were also earning recognition for their historical value (Aldous 1960; Fergusson 1962: 243; NSIS 1963:204). 
difficult for biologists to consult with physicists, and physicists tend to speak only with God?" (Dingle 1962).

With an unprecedented membership of 200 still rising in 1950, the postwar NSIS faced the unfamiliar dilemma of either becoming "unwieldy," or "losing ground" if it did not continue to expand in proportion to the "rapidly increasing" scientific community around it. Either way, the Institute soon replaced its habitual "concerted drive for new members just for the sake of it," with concern to persuade a greater proportion of almost 300 members in 1953 to attend meetings and to volunteer research papers, an area in which the expected influx never materialized (NSIS Minutes: 26 October 1953). One response was finally to schedule meetings in regional research centres, including those conducting agricultural research in Wolfville, Truro, and Kentville, followed by the reorganization in 1952 of the NSIS Annapolis "Valley Chapter" at Acadia University, with a healthy 35 charter members and counting (Weld 1953; Cameron 1954; Chute 1955; NSIS Minutes of Council 7 Nov 1955; Smith 1958; Dingle 1962).

Despite the reminder by president JG Aldous in 1958 that "by 'scientific' I mean seeking by experiment, the answers to questions concerning natural phenomena" (Aldous 1961), the early $20^{\text {th }}$ century's pervasive logical positivism was giving way, at least at its edges, to a broader range of scientific sensibilities. With government research laboratories "primarily intended to assist local industries and the development of the Atlantic region generally" under a narrow Experimentalist understanding of industrial research that urged even colleagues working on "fundamental" problems to choose topics with obvious applications to industry (Dingle 1963:202), new approaches to biological research renewed the need for - and restored recognition of the scientific validity of - evidence from the field as a "disciplinary marker" (Nielsen, Harbsmeier, and Ries 2012:9).

For example, the Valley Chapter reinforced a growing cluster of NSIS members whose research in Nova Scotian ecology would have pleased Harry Piers. Ecology, which studies organisms in relation to their environment, refashioned earlier Natural Historical and Analytical approaches to the natural world (Somers 1876; Lindsay 1876) by applying recent insights from biological, physical, and social sciences: while working within the framework of Experimentalist Ways of Knowing, it nevertheless required regional fieldwork. Besides the pioneering contributions to this transition by W.F. Ganong (Ganong 1901, 1904, 1913; Wynn 1981), a note from the Ecological 
Society of America (established in 1915) had prompted the NSIS to appoint a committee in 1917 to consider "the preservation of areas of peculiar interest for ecological study" (NSIS Minutes of Council: 30 November 1917), albeit with no apparent follow-up. As wartime crises took priority, the ensuing heyday of industrial research had by 1921 ensured the quiet demise of the Canadian Commission of Conservation, overshadowing both ecological and conservationist concerns during the decades that followed (Girard 1991).

Yet highly praised ecological studies did begin to reach NSIS meetings and appear in its Proceedings during these years (Hayes 1926ab; Piers 1938:283-285; Pettingill 1939; King 1940:48; Dore and Roland 1942). Nova Scotia's provincial botanist, AE Roland (d. 1991) of the Nova Scotia Agricultural College in Truro, pointedly verified Harry Piers's earlier concern, explaining in 1941 that "During the last thirty years the local botanists have been almost entirely inactive," leaving the field to "outside specialists" from the United States and Europe (Roland 1941). Roland elaborated several years later: while regional work on Nova Scotian plants had actually been accruing for decades at the Provincial Museum, it all too often remained unpublished (Roland 1946).

Roland's "Flora of Nova Scotia" took up the slack by occupying an entire oversized issue of the NSIS's Proceedings, which sold out several reprint editions, and continues to do so. This new publishing phenomenon revived the NSIS's original understanding that its scientific importance rested precisely in its regional contributions to larger scientific problems (Roland 1946; Weld 1951:51; Chute 1956:40). Other ecological studies repeated this pattern, in several instances again comprising entire issues of the Proceedings that attracted sufficient attention to require reprints - and providing the NSIS with a welcome new source of income (Gorham 1948; Livingstone 1953; Ferguson 1953; Erskine 1954; Pickett 1956; Archibald 1958; Bousfield 1958; Vickery 1961; Loucks 1962). A similar series emerged from the Valley Chapter, originating in the Perry Biological Laboratories and other Departments at Acadia University (Bentley and Smith 1956; Webster 1956; Erskine 1958; MacLellan 1958; Bentley and Smith 1960; Moore 1963). ${ }^{28}$ As a result, the Institute's centenary celebrations in 1962 elicited appreciative remarks from the lieutenant governor, Major General EC Plow (1904-88), who singled out its "extensive

${ }^{28}$ These represent only a sampling of ecological papers from both the Halifax and Wolfville meetings. 
publications on the flora and fauna of the Province in recent years" (NSIS 1964:262).

These celebrations also featured keynote lectures by two distinguished scientists whose work reflected broader issues of popular interest and concern: HB Newcombe of the Biological Branch, Atomic Energy of Canada, a pioneer analyst of the effects of radiation on human health, spoke on "Man and His Genes" to audiences in both Halifax and Wolfville; and Sir Bernard Lovell, Professor of Radio Astronomy and director of the Jodrell Bank Experimental Station, University of Manchester, drew 600-800 people to his talk on "The Exploration of Outer Space" (Archibald 1964:18). The NSIS also made good its earlier intention, commissioning a scholarly NSIS history by CB Fergusson, the provincial archivist, who enjoyed access to the NSIS Minutes as far as $1936^{29}$ (Fergusson 1962; NSIS Minutes of Council 1956: 12 March).

\section{CLEAR(ER) SKIES}

The NSIS thus embarked on its second century with every reason to lead with its obvious strengths, even as some members continued to conflate ecology with natural history (Masson 1968a:253-255; Masson 1968b). The upshot was an impressive succession of thematic and monographic ${ }^{30}$ Proceedings dedicated to international ecological and oceanographic ${ }^{31}$ conferences held in Halifax (Volumes 27, 42, 43); to landmark events such as the Atlantic Regional Laboratory's $25^{\text {th }}$ anniversary in 1977 (Volume 28); and increasingly to environmental $^{32}$ topics (Volumes 27, 30, 42) - as concern over the oil crisis, pollution, genetic engineering, and the industrialized over-harvesting of natural resources gave traction during the 1970s to a burgeoning environmental movement in Atlantic Canada, and in Canadian society more generally ${ }^{33}$ (Cameron 1974:92; Wynn 2013:248-253).

${ }^{29}$ More recent historical analyses walk a tightrope without a balancing pole, with no NSIS Minutes entrusted to archival care after 1958, despite promises in 1999 to "complete" the NSIS's archival record (Niven 2001).

${ }^{30}$ Ian MacLaren's "The Birds of Sable Island" demonstrated the extent to which the NSIS Proceedings had become an important historical source of ecological and environmental information (MacLaren 1981; see also NSIS 1992:148).

${ }^{31}$ Dalhousie University's Institute of Oceanography had been founded in 1959.

${ }^{32}$ Dalhousie University's Institute for Environmental Studies had been founded in 1974.

${ }^{33}$ By 2003, the NSIS distinguished Environmental from Life and Physical Sciences as the categories for its Student Science Awards (NSIS 2004). 


\section{A. Fundamental Questions}

Not far behind, as always, were uneasy members who expressed "real concern" for "the status of its Journal." "We have," argued the NSIS president in 1962:

Never had a very clear cut idea about the role it should fill. It had been used recently for recording rather long detailed studies of local flora and fauna, studies that would probably not be received elsewhere because of their length and limited interest. This is a very useful thing to do and a real purpose has been served; articles of this sort should be published in the future in ever increasing numbers. But the time may be upon us when we should widen the scope of our acceptances ... if we manage to solve our financial problems (Archibald 1964:20-21).

Unexpected ironies continued, first because the Council used the Proceedings' recent focus on regional studies to justify its (successful) application for a quadrupled government grant (from \$500 to \$2000) on an annual basis to keep the journal afloat; and secondly, because papers on other topics were - still - simply not forthcoming (Roland and Smith 1966 and 1969; McCarter 1966:240; McCarter 1968:248). Stagnating membership numbers, at about 100 out of a regional research community of some 800 , declining attendance at regular meetings, and vanishing Student memberships moved the Council in 1965 to appoint a committee "to consider the role of the Institute in the scientific community," with no clear answers arising during a period of repeated inquiries as to the NSIS's basic purposes. These discouraging realities became dire when the provincial government unexpectedly reduced its annual grant to $\$ 500$, pressing the NSIS once again to reaffirm the regional - and increasingly lucrative - focus of the Proceedings ${ }^{34}$ (Masson 1968a:253-255; Masson 1968b; NSIS 1971; Blanchard 1974; Wangersky 1977).

While others expressed frustration with the NSIS's fundamental dilemma, how best to "serve science effectively" in the face of the fundamental fragmentation that had become "a fact of modern life" 35

34 The financial burden was eventually shared by NSERC, Acadia and Dalhousie Universities, the Technical College, and the Nova Scotia Museum, which showed itself a staunch ally of the NSIS in myriad ways during this period (Vining 1981; Forrest 1988).

35 The British scientist and author CP Snow (1905-80) had famously warned in The Two Cultures and the Scientific Revolution. (1959) that the failure of scientists and humanists to communicate in modern society precluded the solution of important problems. 
(McCarter 1968:248), President HBS Cooke's imaginative effort in 1968 to "get back to the kind of atmosphere which was created for people in a wide variety of disciplines" by the NSIS a century earlier, led him to apply the kind of insight that critical theories in philosophy and sociology ${ }^{36}$ had to offer. What the NSIS needed, Cooke suggested, was a "modern interpretation of the objectives for which the Institute was founded":

Just as many of the amateurs of that time were laymen in the strict sense of the word, yet were learned in one branch of knowledge in proportion to the scientific knowledge of the time, so today the average scientist is a layman in all sciences other than his own. It seems to me that we should concentrate very much more on well-organized interdisciplinary discussion which might try to break across the artificially created barriers of narrow specialization (author's italics; Cooke 1968:268-269).

Indeed, recent meetings had already seen animated audiences engaging in exploratory discussions that were led by specialists who could make cross-disciplinary connections. Besides the habitual focus on "the machinery of putting scientific knowledge to use in society," which remained important, it was becoming clear - with the new scholarly disciplines of history and philosophy of science emerging - that "The philosophical aspects of scientific endeavor should not be neglected" (Dyer 1968:263). Along these lines, 110 people in 1971 attended an informed critique of Canada's science policy by the distinguished ecologist and former NSIS president FR Hayes (1904-82), who had founded Dalhousie's Institute of Oceanography in 1959, and chaired the Fisheries Research Board (1964-69); Hayes expanded his influential critique in The Chaining of Prometheus: Evolution of a Power Structure for Canadian Science (1973) and went on to establish Dalhousie's Institute of Environmental Studies in 1974.

In keeping with this new critical spirit - in the sense of understanding science's limitations, along with its possibilities, in terms of the broader cultural contexts that gave it meaning - the NSIS co-sponsored

${ }^{36}$ Michel Foucault's influential The Order of Things: An Archaeology of the Human Sciences (1966) might be the most obvious example of a burgeoning critical literature with science as its focus. 
(in partnership with the AC Neish Memorial Trust) a series of AC Neish Memorial Lectures at Dalhousie University. Neish (1916-73), Dalhousie University's eminent biochemist and NRC Distinguished Research Scientist, had served as NSIS president in 1969-70, and had recently been inducted into both the Order of Canada and the Royal Society of London when he died in 1973. "Always deeply concerned about the future development of science and its impact on society," Neish inspired the lecture series intended "to foster understanding of science by providing the opportunity for members of the public to hear the views of distinguished scientists on the broader aspects of science and by giving them a chance to express their opinions during a question period." For, as one of the event's hosts pointed out, apparently with some surprise, "Despite the material well-being and leisure which science (and compound interest) have won for mankind, there still exists a deep-rooted and widespread irrational fear and distrust of science" (Simpson 1974; Manske, Masson, and McInnes 1977:106).

The four Neish lecturers offered interesting, thoughtful, deeply informed, and timely analyses in their efforts to open new paths of communication between science and society. The first, RHF Manske (1901-77) of the University of Waterloo, exhorted scientists and humanists alike to a mutual awareness of science and its social implications as a matter of "Science, Society, and Survival" in 1974 (Manske, Masson, and McInnes 1977). The second, AW Galston (1920-2008), Eaton Professor of Botany at Yale University, drew from his experience in North Vietnam to discuss the dangers of chemical defoliants in "Science and Social Concern: A Case Study from Plant Physiology" in 1977 (Blanchard 1978; Galston 1978). The third, FR Hayes, showcased the breadth of his knowledge in discussing the biologist EO Wilson's (1929-) controversial evolutionary theories of human culture in "The evolutionary basis for religious belief: Marx's takeover bid for Darwinian sociobiology" in 1978 (Wilson 1975; Cameron 1979; Hayes 1979). The fourth and final Neish lecturer, David Pimentel of Cornell University, tackled the timely issue of overpopulation in "Food, Energy, and the Environment" in 1980 (Pimentel 1981). In a wonderful capstone to the Institute's long list of speakers who resonated with the public - allowing it to peek behind the veil of science - during these years, the lecture by Stephen Jay Gould (1941-2002) of Harvard University, on "Pattern and Non-Pattern in the History of 
Life" ${ }^{37}$ celebrated the NSIS's $125^{\text {th }}$ anniversary in 1987 with a record audience of 1100 (Bligh 1989).

\section{B. Finding a Voice}

Entering its most recent quarter century with a clear understanding of the need "to ensure that the community was well represented in the Institute," the NSIS welcomed the Science Teachers of Nova Scotia, Halifax's recently established Discovery Centre for science, local undergraduate science students, and Dalhousie University's Faculty of Engineering with observer status at NSIS Council meetings over the next few years. It also organized well-received panel discussions as "a further step in the examination of science in general e.g., strategies, research quality, funding and education." In a related outreach strategy, the Institute approached a public relations class at Mount St. Vincent University "to assist us in developing a heightened profile in the community" 38 that soon included involvement in school science fairs, science prizes, student mentorships, a science Hall of Fame, and forums on pressing popular issues such as climate change (Stewart 1993; Stewart 1994; Betts 2004; McCulloch 2005; O’Halloran 2008).

Conversely, the NSIS's Valley Chapter disappeared from its proceedings after 1988. Government cutbacks and university restructuring during the 1990s gave regional scientists a newly defensive common cause - and a concerned NSIS new opportunities to mediate in the other direction: to sponsor a meeting of engineers and scientists, to publish a directory of Nova Scotia's research facilities, and even to press government officials to support "basic [as distinct from applied and increasingly commercialized] science research." "Providing a collective voice for scientists in Nova Scotia," the Council declared in 1997, constituted one of its "main activities." Indeed, as president SH Heaps pointed out in 1998, "There is perhaps no other organization in Nova Scotia that is so well prepared to fill this role." Under these circumstances, he recognized, it was important to increase memberships "not primarily to collect more membership fees, but in order that we can claim to represent a larger cross-section of the concerned public" - from there, according to his successor, to take

${ }^{37}$ Gould had just published Time's Arrow, Time's Cycle: Myth and Metaphor in the Discovery of Geological Time (1987) and was working on Wonderful Life: The Burgess Shale and the Nature of History (1989).

${ }^{38}$ Students drew up a plan as one of their assignments; perhaps as a result, the Council hired a Publicity Officer in 2000 (Betts 2001). 
on a role of active advocacy, "lobbying on behalf of the scientific community in Nova Scotia" and updating its mission statement with a commitment "to represent and promote science" (White ${ }^{39}$ 1996; Gupta 1996; NSIS 1997; Heaps 2001; Niven 2001; NSIS 2008). To counter any implication that the days of JG MacGregor were over, however, President DHS Richardson deftly left no doubt, the following year, of the NSIS's "mission of presenting and promoting science, especially research" long recognized as "an endless undertaking" (author's italics; Richardson 2010; King 1940).

\section{CONCLUSION}

The NSIS really should be congratulated, in its $150^{\text {th }}$ year, for having fulfilled its early members' hopes and dreams and, in particular, for having survived the brutal vagaries of the $20^{\text {th }}$-century battle between time and place, with its soul intact. Its lengthy history is replete with dilemmas and dichotomies, with choices to be made not once, but many times over under changing circumstances: between city and countryside, where interested members have always resided; between increasing specialization in science and a public increasingly unable to comprehend its work without mediation; and between internal unity and disciplinary sectionalism, a choice that the Institute - unlike some other scientific societies - consistently decided must favour the former. Perhaps most importantly, the nature of the NSIS's commitment to science itself changed in tone, emphasis, and venue in response to shifting Ways of Knowing that repeatedly redefined the demands and expectations of both science and society over the course of the NSIS's existence. During its most recent 25 years it has found useful ways to serve both masters - and many of their rival constituencies - in the role of honest broker.

Some NSIS successes required little more than the "alert passivity" of a traveller with limited means hitchhiking to his next destination: "The thumb was perpetually in the traditional position but the head was shaken [at] several offers of a 'lift"' until more promising options appeared. In truth, such examples of good luck were few and far between, except perhaps when a potential NSIS speaker happened into the region for other reasons. Instead there was hard work behind repeated calls to "discover our essential self, lay it bare, and then foster

39 Dr. Mary Ann White served as the NSIS's first woman president in 1994-95. 
it delicately and with loving care. The fact that our Institute has an essential self," attested WJ Archibald in 1962:

And that this self has in some measure been well-served, is indicated by observing that we have survived for one hundred years. No institution that fails to meet a need will last this long. It is not too easy to cut away cant and pomposity and see the true basis on which our permanence lies. Sometimes we claim that we are fostering this, promoting that, pursuing the other thing, and such meaningless phrases; however, I suspect that what really keeps us going is that we enjoy each other's company, we respect each other's ability, we are proud of each other's success, and that we value the chance to talk to each other about our work, to have it criticized and discussed in a friendly spirit. This is a perfectly sound basis for a successful society provided the topics discussed are important and relevant to a certain number of those present at each meeting (Archibald 1964).

Yet that could not be all there has been to it. As RJ Bean noted in 1942, "we would do well to think of our publication as the keystone of our whole organization":

At times, the torch which we now carry has flickered dimly for various reasons, but never more seriously than when opinions that the journal should be discontinued, are cast about. We have been so accustomed over a period of years to the idea of huge enterprises, colossal figures, and concentrated power, that we often lose the sense of perspective which once lead [sic] us to consider that modest enterprise and limited activities were useful and worthwhile (Bean 1946).

This direct link between the NSIS Proceedings and the Institute's sense of its own well-being has always carried a powerful financial dimension. The decision to invest its funds in 1999 saw annual reports of the NSIS having attained more solid ground, but only while the recent policy of combining several years of Proceedings in fewer volumes, as they became more and more expensive to produce, 
allowed the illusion of a slush fund to persist (Stewart 1996; Heaps 2001; Betts 2001).

Perhaps more importantly, the Proceedings have allowed the Institute, in the face of the presumption that dominated in science as industrial research during the early $20^{\text {th }}$ century, once again to find its Nova Scotian moorings. As science itself came under unprecedented critical examination, the Institute chose not retreat but advance, hosting critical perspectives on social dimensions of modern science; and publishing, in the anniversary issue of the Atlantic Regional Laboratories, recollections of the difficult manoeuvrings by NSIS members behind the scenes to ensure the NRC's commitment to funding this important regional research centre. Pursuing this reaffirmation of its fundamental connection to place in a changing world, a born-again NSIS has more recently turned its Proceedings, along with the myriad digital resources it has made available, to recapture their role as the appropriate venue for publications of regional importance across the broadest spectrum of science, including original reviews of contemporary scientific issues from a critical regional perspective.

Without the Institute's unbroken series of published Proceedings now digitized, and still a point of pride for their "worldwide" reach - there could be no history of this singular organization, because not enough of its unpublished records have survived, and not enough of what remains has been made accessible (where else but from minutes of meetings can we learn that "boiled [ie., heavily starched] shirts" were de rigeur attire for Major General McNaughton's NSIS audience in 1937 (NSIS Council Minutes 1937: 1 February)? Or that a large NSIS audience gathered late one night in 1922 to hear for the first time a musical radio programme transmitted from New York (NSIS Minutes 22 May 1922)?) The Proceedings not only harbor fascinating NSIS perspectives on scientific theories as they came and went over time; synopses of impromptu discussions that followed such presentations also offer invaluable hints of their reception, along with that of steam power and other technological wonders, including electric lighting. Maddening enticements continue to lurk in those 150 years of published pages, begging for historical and scientific follow-up. (Who knew that NSIS members anticipated television in 1926 as "just around the corner" (Ritchie 1926b); and that later generations dreamed of an NSIS television programme (Gupta 1996)?) What stands out overall, however, is that fascinating, fundamental, and, 
at times, ruthless struggle between time and place in the Institute's history, and the gratifying fact that place continues to hold its own.

Acknowledgements The author wishes to thank Jennifer Coggon, Bertrum MacDonald, Eric Mills, Michelle Paon, Lois Yorke and the staff of the Nova Scotia Archives, Peter Wells and Gail LeBlanc, for their kind help during the various stages of this research.

\section{REFERENCES}

Ainley, M.G. (1988). Rowan vs. Tory: conflicting views of scientific research in Canada, 1920-1935. Scientia Canadensis 12(2):3-21.

Aldous, J.G. (1960). Presidential Address for 1957. NSIS Proceedings 24(4):399-403.

(1961). Presidential Address for 1958. NSIS Proceedings 25(1):71-74. .

Ambrose, J. (1867). Observations on the sea-birds frequenting the coast of St. Margaret's Bay, N.S. NSIS Proceedings and Transactions 1(3):51-59. Archibald, K.D. (1958). Forest aphidae of Nova Scotia. NSIS Proceedings 24(2):1-254.

Archibald, W.J. (1964). Presidential Address for 1962. NSIS Proceedings 26(1):18-21.

Austen,I. (2000). Grassroots science. Canadian Geographic. May/June: 76.

Bailey,H.S. (1972). The background of the Challenger expedition. American Scientist 60(5):550-60.

Basalla,G.(1967).The spread of Western science. Science 156(3775):611-22.

Bean, R.J. (1942). Presidential Address for 1941. NSIS Proceedings 20(4):288-292.

----- (1946). Presidential Address for 1942. NSIS Proceedings 21(1):1-4 .

Belt, T. (1867). List of butterflies observed in the neighbourhood of Halifax, NSIS Proceedings and Transactions 1(2):87-91.

Bentley, P.A. \& Smith, E.C. (1956). The forests of Cape Breton in the seventeenth and eighteenth centuries. NSIS Proceedings: 24(1):1-15.

----- (1960). A study of Northern White cedar and Jack pine in Nova Scotia. NSIS Proceedings 24(4):376-398.

Berger, C. (1996). Honour and the search for influence: a history of the Royal Society. of Canada. University of Toronto Press, Toronto.

Betts, D.D. (2001). Presidential Address for 2000. NSIS Proceedings 41(4):230-231 .

----- . Presidential Address for 2001. NSIS Proceedings 42(2):437-438.

Bishop, W.L. (1912). Presidential Address for 1911. NSIS Proceedings and Transactions 13(2):xxiii-xxvi.

Blanchard, J.E. (1974). Presidential Address for 1973. NSIS Proceedings 27(2):98-99.

----- (1978). The second A.C. Neish memorial lecture: Introduction of AW Galston. NSIS Proceedings 28(1/2):35. 
Bligh,E.G.(1989). Presidential Address for 1987. NSIS Proceedings 38(3-4).

Bousfield, E.L. (1958). Littoral marine arthropods and molluscs collected in western Nova Scotia. NSIS Proceedings 24(3):303-325.

British Association for the Advancement of Science [BAAS]. (1885). Report of the fifty-fourth meeting ... at Montreal in August and September 1884. Kojn Murray, London.

Cameron, A.E. (1954). Presidential Address for 1948. NSIS Proceedings 23(2):149-149.

Cameron, M.L. (1974). Presidential Address for 1971. NSIS Proceedings 27(2):91-93.

--- (1979). The third A.C. Neish memorial lecture: Introduction to F.R. Hayes. NSIS Proceedings 29(2):133.

Chute, W.J. (1955). Presidential Address for 1953. NSIS Proceedings 23(4):109-110.

---- (1956). Presidential Address for 1954. NSIS Proceedings 24(1): 39-40.

Coffin, C.C. (1950). Presidential Address for 1948. NSIS Proceedings 22(3):36-37.

Cooke, H.B.S. (1968). Presidential Address for 1968. NSIS Proceedings 26(3):266-271.

Corfield, R. (2003). The silent landscape: the scientific voyage of HMS Challenger. Joseph Henry Press, Washington.

Creighton, H.J.M. (1919). A method for making methyl violet. NSIS Proceedings and Transactions 15(1):57-61.

Dalhousie Gazette. (1913). Editorial, 13 September: 2-43.

Dewar, A. (1865). Contributions to the game of Nova Scotia. Nova Scotia Archives, MG 20 Volume 226, NSIS Minutes, Ordinary Meeting, 6 February.

---- (1879). Magnetism, the life of the world. NSIS Proceedings and Transactions 5(1):58-64.

Dingle, J.R. (1962). Presidential Address for 1959. NSIS Proceedings 25(2):168-171.

----- (1963). Presidential Address for 1959. NSIS Proceedings 25(3):199-202:.

Doane, F.W.W. (1908). Presidential Address, 1906. NSIS Proceedings and Transactions 9(1):i-ix.

Dore, W.G. \& Roland, A.E. (1942). The grasses of Nova Scotia. NSIS Proceedings 20(4):177-288.

Dyer, W.J. (1968). Presidential address for 1967. NSIS Proceedings 26(3):262-263.

Erskine, J.S. (1954). The ecology of Sable Island, 1952. NSIS Proceedings 23(2):120-145.

----- (1958). A study of the Tusket Islands. NSIS Proceedings 24(3):271-296.

Fenech, A. (1999). Examples of innovative information management for reporting forest data and information, USDA Forest Service Proceedings: 460-472.

----- et al (2005). Impact of climate on changes in the seasonal timing of life cycle events of eastern Canada from 1901 to 1923. Integrated Mapping Assessment, Fenech A. et al. (eds.). Environment Canada, Toronto: 55-69. 
Ferguson, D.C. (1953). The Lepidoptera of Nova Scotia. NSIS Proceedings 23(3):161-375.

Fergusson, C.B. (1962). The Nova Scotian Institute of Science. NSIS Proceedings and Transactions 25(4):215-53.

Fergusson,D.M.(1915a). Presidential Address for 1913. NSIS Proceedings and Transactions 13(4):cxiii-cxxii.

---- (1915b). Presidential Address for 1914. NSIS Proceedings and Transactions 14(1):i-v.

----- (1916). Presidential Address for 1915. NSIS Proceedings and Transactions 14(2):ix-xix.

Forrest, T.P. (1988). Presidential Address for 1987. NSIS Proceedings 37(3-4):154.

Fraser,T.R.(1868). Magnetism and its connection with the telegraph.NSIS Proceedings and Transactions 2(2):36-42.

Galston, A.W. (1978). Science and social concern, a case history from plant physiology. NSIS Proceedings 28(1/2):36-39.

Ganong, W.F. (1901). A laboratory course in plant physiology especially as a basis for ecology, Henry Holt and Company, New York.

----- (1904). The cardinal principles of ecology, Science n.s. 19 (482):493-498.

----- (1913). The living plant, Henry Holt and Company, New York.

Gates, R.R. (1941). Some recent aspects of genetics. NSIS Proceedings 20(3):127-140.

Gilpin,E.(1878). On the necessity for preliminary scientific training for civil and mining engineers. NSIS Proceedings and Transactions 4(4):379-390.

Gingras, Y. (1991). Physics and the rise of scientific research in Canada. McGill-Queen's University Press, Montreal and Kingston.

Girard, M. (1991). The Commission of Conservation as a forerunner to the National Research Council 1909-1921. Building Canadian Science: The Role of the National Research Council. Scientia Canadensis 15(2):19-40.

Gorham, E. (1948). Bryophytes and lichens in the pastures of the Maritime provinces. NSIS Proceedings 22(1):1-10.

Gossip, W. (1878). Anniversary address, 1876. NSIS Proceedings and Transactions 4(2):226-32.

(1879). Anniversary address, 1879. NSIS Proceedings and Transactions 5(1):99-111.

----- (1884). (Appendix) Report by Wm. Gossip, Esq., delegate to the Royal Society at Ottawa, May 1883. NSIS Proceedings and Transactions 6(2):i-xii.

----- (1885). Paper by Wm. Gossip, Esq. NSIS Proceedings and Transactions 6(3):155-166.

Grant, G. (1892). President's address 1891. RSC Proceedings and Transactions 9:xxx-xl.

Guildford, J. (2003-). MacKay, Alexander Howard. Dictionary of Canadian Biography 15. University of Toronto/ Université Laval, Toronto and Quebec, accessed 16 October 2013 http://www.biographi.ca/en/bio/ mackay_alexander_howard_15E.html. 
Gupta, R.P. (1996). Presidential Address for 1996. NSIS Proceedings 41(1-20:57-58.

Hall, C.F. (1896). Report from the NSIS for 1896. RSC Proceedings and Transactions. Ser. 2, Vol. 2: xxxvii-xxxviii.

Harris, D.F. (1918). The man of science in the community today (13 November 1916). NSIS Proceedings and Transactions 14(2) xxxv-lxii.

Hayes, F.R. (1926a). The negative geotropism of the periwinkle: a study in littoral ecology. NSIS Proceedings and Transactions 16(4):155-173.

---- (1926b). The effect of environmental factors on the development and growth of Littorina littorea . NSIS Proceedings and Transactions 17(1):6-13.

----- (1948). Presidential Address for 1946. NSIS Proceedings 21(1):11-13.

---- (1973). The chaining of Prometheus: evolution of a power structure for Canadian science. University of Toronto Press, Toronto.

---- (1979). The evolutionary basis for religious belief: Marx's takeover bid for Darwinian sociobiology. NSIS Proceedings 29(2), 134-145.

Henderson, G.H. (1939a). Presidential Address for 1937. NSIS Proceedings and Transactions 19(4):439-442.

---- (1939b). Presidential Address for 1938. NSIS Proceedings and Transactions 20(1):21-26.

Hill, P.C. (1867). Inaugural address,1863. NSIS Proceedings and Transactions 1(1):1-4.

Haycock, E. (1902). NSIS Proceedings for 1901. NSIS Proceedings and Transactions 10(4):cix-cxi.

Heaps, S.H. (2001). Presidential Address for 1998. NSIS Proceedings 41(4):227-228.

Honeyman, D. (1873). Appendix: the Challenger scientific expedition visit to Halifax. NSIS Proceedings and Transactions 3(3):335-37.

---- (1874). On the deep sea, in Appendix: Conversazione. NSIS Proceedings and Transactions 3(4):439.

---- (1877). On Nova Scotian Geology. Nova Scotia Archives, MG Volume 226. NSIS Minutes, Vol. 1, Ordinary Meeting, 12 February.

---- (1885). Geological notes of excursions with members of the British Association, and others. NSIS Proceedings and Transactions 6(3):166-174.

Howell, C.D. (2003). Parker, Daniel McNeill. Dictionary of Canadian Biography 13. University of Toronto/ Université Laval, Toronto/ Quebec, accessed October 10, 2013 http://www.biographi.ca/en/bio/parker_daniel_mcneill_13E.html.

Hubbard, J. (2006). A Science on the Scales: The Rise of Canadian Atlantic Fisheries Biology, 1898-1939. University of Toronto Press, Toronto.

Johnson, A. (1891). Tidal observations in Canada. RSC Proceedings and Transactions 8 Section III:57-60.

Johnstone, J.H.L. (1927). Presidential Address for 1927. NSIS Proceedings and Transactions 17(2):xi-xiv.

---- (1928). Presidential Address. NSIS Proceedings and Transactions 17(3):xviii-xxiv.

Jones, J.M. (1867). A fortnight in the backwoods of Shelburne and Weymouth. NSIS Proceedings and Transactions 2(1):48-60. 
King, H.S. (1940). Presidential Address for 1939. NSIS Proceedings 20(2):47-49.

----- (1941). Presidential Address for 1940. NSIS Proceedings 20(3):141-148.

Knight, T.F. (1870). Natural history, and its place in the sciences. NSIS Proceedings and Transactions 2(3):88-100.

Knott, C.G. (1913). Prof. James Gordon MacGregor, FRS. Nature 91 (29 May): 323-324.

Lawson, G. (1888). Vice presidential Address 1887. RSC Proceedings and Transactions 5:xxii-xxv.

----- (1889). Presidential address 1888. RSC Proceedings and Transactions $6: 1-12$.

---- (1892). On the present state of botany in Canada. RSC Proceedings and Transactions 8:17-20.

---- (1896). Annual Address 12 November 1894. NSIS Proceedings and Transactions 9(1):i-xi.

Leim, A.H. (1935). Presidential address for 1933. NSIS Proceedings and Transactions 18(4):286-288.

Levere, T. (1998). Research and influence: a century of science in the Royal Society of Canada. Scientia Canadensis 20:1-98.

Lindsay,A.W.H.(1876). (Appendix) A catalogue of the flora of Nova Scotia, arranged according to Gray's Manual of Botany for the N. United States of America. NSIS Proceedings and Transactions 4(2):184-222.

Livingstone, D.A. (1953). The fresh water fishes of Nova Scotia. NSIS Proceedings 23(1):1-90.

Livingstone, D.N. (2003). Putting science in its place: geographies of scientific knowledge. University of Chicago Press, Chicago.

Loucks, O.L. (1962). A forest classification for the Maritime provinces. NSIS Proceedings 25(2):85-167.

MacGregor, J.G. (1886a). Appendix to the proceedings: report of the committee ... for the encouragement of original literary and scientific work. RSC Proceedings and Transactions 3:xxix-xli.

----- (1886b). Report from the NSIS. RSC Proceeding s and Transactions 3:x.

----- (1890a). Opening address 1888. NSIS Proceedings and Transactions 7(3):185-196.

----- (1890b). Opening address 1889. NSIS Proceedings and Transactions 7(4):319-336.

-- (1892a). Opening address 1890. NSIS Proceedings and ransactions 8(1):i-v.

----- (1892b). Annual address 1891. NSIS Proceedings and Transactions 8(2):xxxi-xxxv.

---- (1898). Obituary notice of Prof. Lawson. Proceedings for 1895. NSIS Proceedings and Transactions 9(2):xxiii-xx.

----- (1899). On the Utility of Knowledge-Making as a Means of Liberal Training. Dalhousie College, Halifax.

MacGregor,J.G.(1913). AScottish tribute. Reprinted in Dalhousie Gazette, 13 September: 5-9. 
MacGregor, J.G. (1913). Personalia. Dahousie Gazette, 13 September: 27-30.

MacKay, A.H. (1893). Natural history observations, made at several stations in Nova Scotia during the year 1892. NSIS Proceedings and Transactions 8(3):378-379.

---- (1894). Phenological observations made at several stations in Nova Scotia and New Brunswick during the year 1893. NSIS Proceedings and Transactions 8(4):451-455.

---- (1896a). Phenological observations made at several stations in eastern Canada during the year 1894. NSIS Proceedings and Transactions 9(1):59-63.

---- (1896b). Phenological observations made at several stations in Canada during the year 1895. NSIS Proceedings and Transactions 9(2), 195-207. (1897). Phenological observations, Canada, 1896. NSIS Proceedings and Transactions 9(3):268-274.

----- (1899). Phenological observations, Canada, 1898. NSIS Proceedings and Transactions 10(1):91-109.

---- (1900). Phenological observations, Canada, 1899. NSIS Proceedings and Transactions 10(2):303-318.

----- (1902a). Phenological observations of the Botanical Club of Canada, 1900. NSIS Proceedings and Transactions 10(3):379-398.

----- (1902b). President's address for 1901. NSIS Proceedings and Transactions 10(4):1xxxiv-xcvii .

----- (1903). Phenological observations in Nova Scotia and Canada, 1901. NSIS Proceedings and Transactions 10(4):486-501.

---- (1905a). President's address for 1902. NSIS Proceedings and Transactions 11(1):i-viii.

---- (1905b). Phenological observations in Nova Scotia and Canada, 1902. NSIS Proceedings and Transactions 11(1):144-157.

---- (1912). Phenological observations in Nova Scotia, 1911. NSIS Proceedings and Transactions 13(2):175-187.

Mackay, E. (1912a). Presidential Address 1908. NSIS Proceedings and Transactions 12(3):xlviii-liii .

(1912b). Presidential Address 1909. NSIS Proceedings and Transactions 12(4):lvii-lxix.

---- (1912c). Presidential Address 1910. NSIS Proceedings and Transactions 13(1):ii-xviii.

Mackenzie, A.S. (1913). Proceedings 13 May. NSIS Proceedings and Transactions 14(4):1xxiii-lxxxii.

MacLellan, C.E. (1958). Abstract: The role of woodpeckers in the natural control of the woodland moth. Proceedings for 1956-57. NSIS Proceedings 24(3):337.

Macleod, D. (2003). Gilpin, Edwin. Dictionary of Canadian Biography Vol. 13. University of Toronto/ Université Laval, Toronto and Quebec. Accessed 26 September 262013 http://www.biographi.ca/en/bio/gilpin_edwin_13E.html. 
MacLeod, R.M. \& Collins, P. (eds) (1981). The parliament of science: the British Association for the Advancement of Science 1831-1981. Science Reviews, Northwood, Middlesex.

Manske, R.H.F., Masson, C.R., \& McInnes, A.G. (1977). The first A.C. Neish memorial lecture. NSIS Proceedings 27(3/4):114-133.

Masson, C.R. (1968a). Presidential Address for 1965. NSIS Proceedings 26(3):252-258.

(1968b). Presidential Address for 1966. NSIS Proceedings 26(3): 259-260.

McCarter, J.A. (1966). Presidential Address for 1963. NSIS Proceedings 26(2):239-240.

----- (1968). Presidential Address for 1964. NSIS Proceedings 26(3): 247-251.

McCulloch, A. (2005). Presidential Address for 2004. NSIS Proceedings 43(1):69-70.

McIntosh, D. (1929). Presidential Address for 1929. NSIS Proceedings and Transactions 17(4):xxxiii-xxxvii.

(1932). Presidential Address for 1931. NSIS Proceedings and Transactions 18(1):14-16.

McKay, A. (1899). Presidential Address for 1898. NSIS Proceedings and Transactions 10(1):i-Xv.

(1900). Presidential Address for 1899. NSIS Proceedings and Transactions 10(2):xxxv-xli .

McKillop, A.B. (1982). The research ideal and the University of Toronto, 1870-1906. RSC Transactions. Series 4: 253-74.

----- (1994). Matters of mind: the university in Ontario 1791-1951. University of Toronto Press, Toronto.

McLaren, I.A. (1981). The Birds of Sable Island, Nova Scotia. NSIS Proceedings 31(1):1-84.

McNaughton, A.G.L. (1938). The organization of research in Canada. NSIS Proceedings 19(3):215-236.

Mellish, J.T. (1878). Ordinary meeting, 8 May 1876. NSIS Proceedings and Transactions 4(2):105.

Mills,E.L.(ed) (1975). 100 years of oceanography: essays commemorating the visit of HMS Challenger to Halifax. Dalhousie University and the Nova Scotia Museum, Halifax.

----- (1989). Biological oceanography: an early history. Cornell University Press, Ithaca.

Moore, R.G. (1963). Land mollusca in the vicinity of Wolfville, Nova Scotia. NSIS Proceedings 25(3):187-198.

Munro, L.A. (1923). A study of molybdenum blue, its properties and composition. NSIS Proceedings and Transactions 16(1):9-24.

Murphy, M. (1893). Opening address 1892. NSIS Proceedings and Transactions 8(3):xlviii-lii.

Nickerson, C.B. (1925). Presidential Address for 1924. NSIS Proceedings and Transactions 16(3):xviii-xx.

Nielsen, K.H., Harbsmeier, M., \& Ries, C.J. (2012). Studying scientists and scholars in the field. Scientists and scholars in the field: studies in 
the history of fieldwork and expeditions. Nielsen, K.H., Harbsmeier, M., and Ries, C.J. (eds). Aarhus University Press, Aarhus, 9-28.

Niven, S.E.H. (2001). Presidential Address for 1999. NSIS Proceedings 41(4): 228-229.

NSIS. (1863). Bye Laws of the Nova Scotian Institute of Natural Science. Jas. Bowes and Sons, Halifax.

NSIS. (1936b). A catalogue of scientific periodicals in libraries of the Maritime provinces. Imperial Publishing Co., Halifax.

---- (1885). Laws of the Nova Scotian Institute of Natural Science. William McNab, Halifax.

NSIS. Minutes of Meetings (1862-1958). Nova Scotia Archives, MG 20

Vols. 226-28.

(1879). Folder 1, Vol. 228.

NSIS. (1863-2012). Proceedings, NSIS Proceedings and Transactions:

(1896). 11 March 1895.9(1):xvi-xvii.

(1897). 12 April. 9(3):xci.

(1906). 10 February 1904. 11(2):xxvii.

(1908). 1906. 10(1):i-x.

(1915). 11 November 1912. 13(3):xlvi-xlviii.

(1916). 22 February. 14(2):xxii-xxiii.

(1919a). 10 October 1917. 11 February 1918. 14(4):1xx-1xxii.

(1919b). 18 May 1918. 14(4):1xxxiii-1xxxix.

(1919c). 12 May. 15(1):v-vi.

(1920). 10 November 1919. 15(2):xxi-xxiii.

(1921). 8 November 1920. 15(3):xxix-xxxi.

(1923). 20 November 1922. 16(1):i-iii.

(1925). 11 May 1925. 16(3):xvii.

(1926a). 14 October 1925. 16(4):xxi-xxiii.

(1926b). 18 January. 16(4):xxiv-xxv.

(1929a). 24 November, 10 December 1928. 17(3):xxvi-xxvii.

(1929b). 15 April 1929. 17(3):xxx.

(1932a). 15 October 1930. 18(1):17-18.

(1932b). 15 April 1931. 18(1):19.

(1936a). 14 October 1936. 19(3):287-288.

(1942). 13 October 1941. 20(4):293-295.

(1955). Proceedings of the Valley Chapter, 1953-54. 23(4):414-415.

(1963). 17 October 1960. 25(3):23-205.

(1964). 9 April 1962. 25(4):263-264.

(1971). 1970. 27(1):28-29.

(1992). Cumulative author and subject indices to the Proceedings of the Institute. 39(4):148-247.

(1997). Atlantic regional workshop on the commercialization of government science research: Summary. 41(3):127-129.

(2004). NSIS student science awards 2003 . 42(2):409-410.

(2008). Revised by-laws of the NSIS. 44(2):231-238.

Naftel, W.D.(2003). Honeyman, David. Dictionary of Canadian Biography Vol. 11. University of Toronto Press/ les presses de l'Université Laval 
[accessed December 12, 2013] http://www.biographi.ca/en/bio/honeyman_david_11E.html.

O'Halloran, M.J. (2008). President's Report for 2008. NSIS Proceedings 45(2):125-126.

Pettingill, O.S. (1939). The bird life of the Grand Manan Archipelago. NSIS Proceedings 19(4):293-372.

Pickett, A.D. (1956). Abstract: some ideas, partially unorthodox, regarding insects. NSIS Proceedings 24(1):55.

Pickstone, J.V.(2001). Ways of knowing: a new history of science, technology, and medicine. University of Chicago Press, Chicago.

Piers, H. (1915). Brief historical account of the Nova Scotian Institute of Science, and the events leading up to its formation. NSIS Proceedings and Transactions 13(3):liii-cix.

----- (1936). Presidential Address for 1935. NSIS Proceedings 19(2):199-201. (1938). Presidential Address for 1936.NSIS Proceedings 19(3):284-285.

Pimentel,D.(1981). The fourth A.C. Neish Memorial Lecture: Food, energy, and the environment. NSIS Proceedings 31(2):85-100.

Poole, H. (1906). Presidential Address, 1903. NSIS Proceedings and Transactions 11(2):xvii-xxiii.

Reid, A.P. (1872a). Anniversary Meeting 9 October. NSIS Minutes Vol. I, Nova Scotia Archives, MG 20, Vol. 226.

----- (1872b). Ordinary Meeting 8 January. NSIS Minutes Vol. I, Nova Scotia Archives, MG 20, Vol. 226.

- (1874). Ordinary Meeting, 9 November. NSIS Minutes Vol. I, Nova Scotia Archives, MG 20, Vol. 226.

----- (1876). Natural history and the fisheries. NSIS Proceedings and Transactions 4(2):131-37.

Ritchie, S.G. (1926a). Presidential Address for 1925. NSIS Proceedings and Transactions 16(4):xxviii-xxxiii.

----- (1926b). Presidential Address for 1926. NSIS Proceedings and Transactions 17(1):viii-ix.

Ross, A. (1874). Evolution. NSIS Proceedings and Transactions 3(4): 410-35.

Roland, A.E. (1941). The ferns of Nova Scotia. NSIS Proceedings 20(3): 4-120.

----. (1946). The flora of Nova Scotia. NSIS Proceedings 21(3):94-642.

Roland, A.E. \& Smith, E.C. (1966). The flora of Nova Scotia, Part I: The pteridophytes, gymnosperms, and monocotyledons. NSIS Proceedings 26(2):4-238.

---- (1969). The flora of Nova Scotia, Part II: The dicotyledons. NSIS Proceedings 26(4):277-743.

Royal Society of Canada. (1882-1892). Proceedings. RSC Proceedings and Transactions:

(1883). Proceedings for 1883. 1:xxvii-lxxv.

(1886). Proceedings for 1885. 3:i-xxviii.

(1891). Proceedings for 1890. 8:i-xlvii.

(1892). Proceedings for 1891. 9:i-1xix. 
Simpson, F.J. (1974). AC Neish. NSIS Proceedings 27(2):103.

Smith, C. (1999). The science of energy: a cultural history of energy physics in Victorian Britain. University of Chicago Press, Chicago.

Smith, H.D. (1958). Presidential Address for 1955. NSIS Proceedings 24(2):255-257.

Somers, J. (1876). (Appendix) Introduction to a synopsis of the flora of Nova Scotia. NSIS Proceedings and Transactions 4(2):181-183.

Stafford, R.A. (1989). Scientist of empire: Sir Roderick Murchison, scientific exploration and Victorian imperialism. Cambridge University Press, Cambridge.

Stewart, J.E. (1993). Presidential Address for 1993. NSIS Proceedings 40(1):55-56.

---- (1996). Presidential Address for 1994. NSIS Proceedings 40(1):53-54.

Tratt, G.E.N. (2003). Gossip, William. Dictionary of Canadian Biography Vol. 11. University of Toronto/ Université Laval, Toronto and Quebec. Accessed 26 September 2013 http://www.biographi.ca/en/bio/gossip_william_11E.html.

Vickery, H.B. (1919). The isochlors of Nova Scotia. NSIS Proceedings and Transactions 14(4):355-370.

Vickery, V.R. (1961). The Orthoptera of Nova Scotia. NSIS Proceedings 25(1):1-70.

Vining,L.C.Presidential Address for 1980. NSIS Proceedings 31(3-4):262.

Waite,P.B.(1994). The lives of Dalhousie University, I: 1818-1925. McGillQueen's University Press, Montreal and Kingston.

---- (2003). MacGregor James Gordon. Dictionary of Canadian Biography Vol. 14. University of Toronto/Université Laval, Toronto and Quebec. Accessed 26 September 2013 http://www.biographi.ca/en/bio/macgregor_james_gordon_14E.html.

Wangersky, P.J. (1977). Presidential Address for 1974. NSIS Proceedings 27(4):174-176.

Webster, D.H. (1956). Notes on the distribution of Potamogeton species and hybrids in Nova Scotia. NSIS Proceedings 24(1):16-24.

Weld, C.B. (1951). Presidential Address for 1949. NSIS Proceedings 22(4):49-53.

---- (1953). Presidential Address for 1950. NSIS Proceedings 23(1):99-102 .

White, M.A. (1996). Presidential Address for 1995. NSIS Proceedings 41(1-2):55-56.

Whyte, E.F. (1921). A study of the extraction of potash from orthoclase feldspar by carbon dioxide and sulphur dioxide. NSIS Proceedings and Transactions 15(3):145-151.

Wilson, E.O. (1975). Sociobiology: the new synthesis. Harvard University Press, Cambridge, MA.

Wynn, G. (2007). Canada and Arctic North America: an environmental history. ABC-Clio, Santa Barbara.

---- (2013). Reflections on the environmental history of Atlantic Canada. Campbell, C. and Summerby-Murray, R. (eds). Land and sea: environmental history in Atlantic Canada.Acadiensis Press, Fredericton, 235-256. 
(1981). Ganong, W.F., Clark, A.H. and the historical geography of Maritime Canada. Acadiensis 10 (1981):5-28.

Yorke, L.K. (2003). McKay, Alexander. Dictionary of Canadian Biography 14. University of Toronto/ Université Laval, Toronto and Quebec, accessed October23,2013,http://www.biographi.ca/en/bio/mckay_alexander_14E. html.

Young, G.E. (1933). Presidential Address for 1931. NSIS Proceedings and Transactions 18(2):68-72.

---- (1934). Presidential Address for 1932. NSIS Proceedings and Transactions 18(3):215-217.

Zeller, S. (2000). Roads not taken: Victorian science, technical education, and Canadian schools, 1844-1913. Historical Studies in Education 12(1-2):1-28.

(2003). Lawson, George. Dictionary of Canadian Biography Vol. 12. University of Toronto/Université Laval, Toronto and Quebec. Accessed 26 September 2013 http://www.biographi.ca/en/bio/lawson_george_12E. html.

(2012). Recalibrating empire: Humboldtian climatology in the reports of the Palliser and Hind expeditions to British North America's Great North West, 1857-60. Kutzinski, V., Ette, O., Walls, L.D. (eds) Alexander von Humboldt and the Americas. Verlag Walter Frey, Berlin, p 70 - 110.

Zwarenstein, C. (2010). Biodiversity: environmental scientist of the year. Canadian Geographic, June 2010, 3 p. 